\title{
DIGITAL TRANSCRIPTION AND ANALYSIS OF THE CARLETON ANTIPHONARY
}

by

\section{KAITLYN BRASSEUR}

A thesis submitted to the Faculty of Graduate and Postdoctoral Affairs in partial fulfilment of the requirements for the degree of

Master of Arts

In

History

Carleton University

Ottawa, Canada

June 29, 2020

C) Copyright 2020,

Kaitlyn Brasseur 


\begin{abstract}
My thesis examines Ottawa, Carleton University Library, Archives and Research Collections Ms. 1 (hereby referred to as the Carleton Antiphonary) as a medieval artefact. Lack of resources devoted to cataloguing has left many North American manuscripts hidden and understudied, and such was the fate of the Carleton Antiphonary. This project digitizes and analyses this unique compound manuscript to increase the accessibility of digital facsimiles. Furthermore, the codicological evidence proves this artefact is worth studying as a devotional object, as it demonstrates longstanding use over the last five hundred years.
\end{abstract}

The goal of this project has been twofold. First, it has been to bring this medieval codex to light by making it accessible online. Secondly, the goal has been to share the process by which others may make medieval materials accessible using open-source tools and the coding purpose made for this project.

To access the website, copy and paste this URL into your preferred browser: https://carleton-antiphonary.herokuapp.com 


\section{Acknowledgements}

I must begin with a very special thank-you to my partner, Ryan. I cannot thank you enough for your invaluable work on the website that has transformed my dream of bringing this medieval book into the digital world a reality. Your encouragement and ability to tolerate endless discussions on medieval monks and nuns, palaeography, and my frustrations with Latin abbreviations has kept me sane. I thank you for your love, patience, and support you give me every day.

Thank you to my wonderful sister Shanna, who has always been on the other side of the phone to encourage me to keep going when things got tough. You have always been my inspiration, my reminder that good things come to those who fight for them. I love you, thank you so much for everything. Merci à Mathieu, qui me fait toujours sentir comme si j'étais chez moi (surtout avec sa délicieuse cuisine nostalgique...mmm tes crèmes brûlées). Et merci aussi à tes deux merveilleux fils, Alix et Zevrik, qui rendent ma vie plus joyeuse et pleine d'amour. Je vous aime tous.

My sincerest thank-you to my supervisor, Marc Saurette. Not only for your work and support for this project, but for your continued faith in me throughout the years. You sparked my love for the Middle Ages and helped me hone my academic skills, I could not have completed this herculean effort without your wisdom and guidance. I simply cannot say how appreciate I am for all your help, thank you.

Thanks to my friends, colleagues, and professors who endured me talking for hours about medieval books. Special thanks to Olivia Richmond, Max Cronkite, Paul Sjöberg, and Shamus McCoy, for your enduring friendship based on a mutual love for history and nerdy things. Thank you to the lovely Jenna Emslie, your humour and friendship emboldened my efforts at just the right time and saw me through to the end.

To my mother and father who gave me a love of history. In childhood, my father and his siblings had me entranced for hours as they regaled me with our family history, complete with amazing photographs. Today, the best historical fiction recommendations and unwavering optimism and pride are always a phone-call away when I need them. I love you both so much.

To my brothers: Andrew, Nicholas, Marc, Dylan, and Benjamin, thank you for teaching me to love learning new things and to always try and see things from multiple perspectives. Andrew, I am sorry you are no longer here, but I hope I have made you proud. I love you all.

To the students of History of the Medieval Book (HIST 4915e) for the passion and hard work you put into our class that sparked my interest in the Carleton Antiphonary. Thank you! And to Lindsay, Savanna, Mattea, Nick P., Angie, Al and Terri, and everyone else who has supported me, thank you. 
Table of Contents

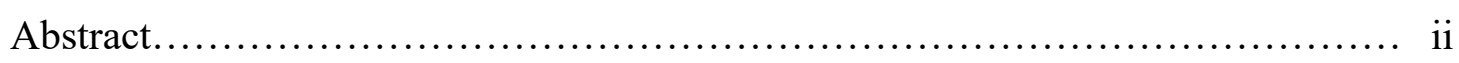

Acknowledgements.............................................................. ii

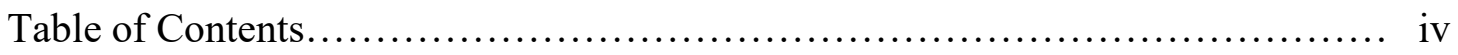

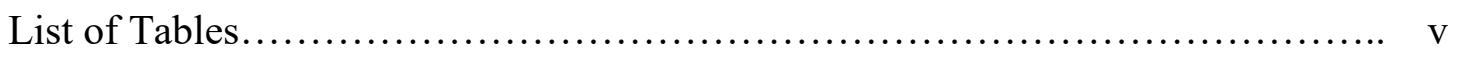

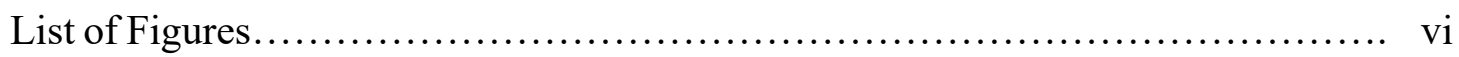

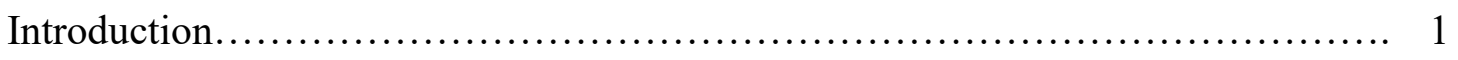

Chapter 1: Physical Description of the Manuscript.............................. 5

1.1 Mise-en-page and Pagination........................................ 5

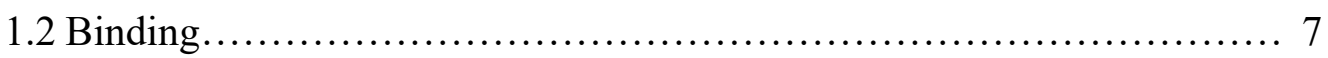

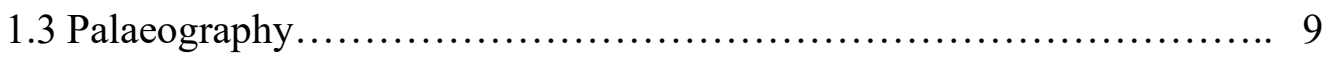

1.4 Corrections and Annotations........................................... 13

1.5 Fragments.......................................................... 16

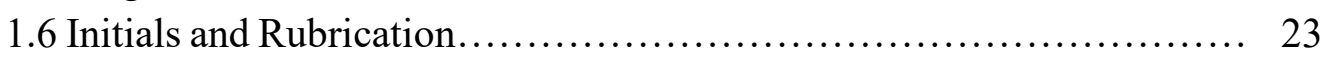

1.7 Writing Support...................................................... 26

1.8 Damages, Repairs and Additions..................................... 27

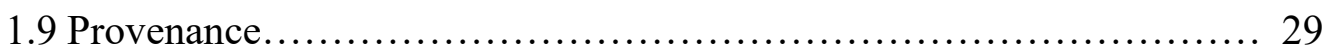

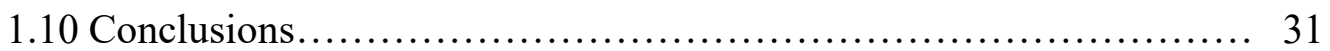

Chapter 2: Contents of the Manuscript.............................................. 33

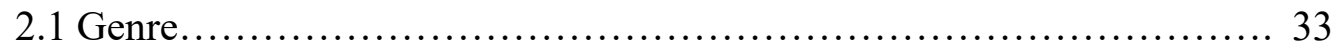

2.2 Structure of the Codex.................................................... 35

2.3 Corrections and Annotations......................................... 42

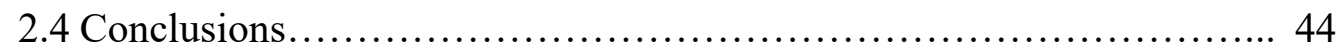

Chapter 3: The Digital Edition................................................. 47

3.1 How to read this edition................................................. 47

3.2 Web Edition vs Paper Edition............................................ 50

3.3 Stages of Production.................................................... 53

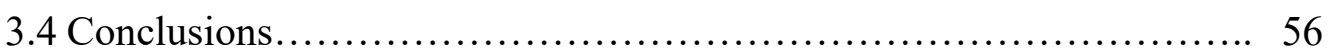

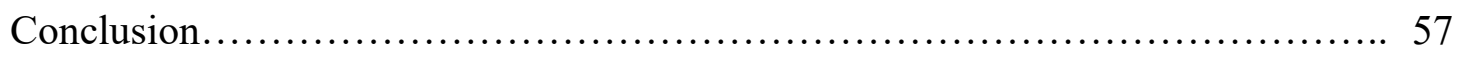

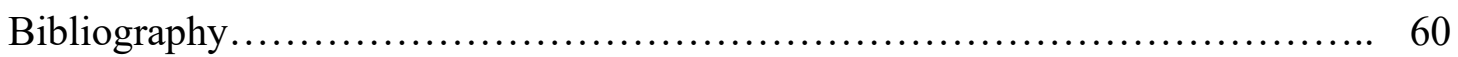

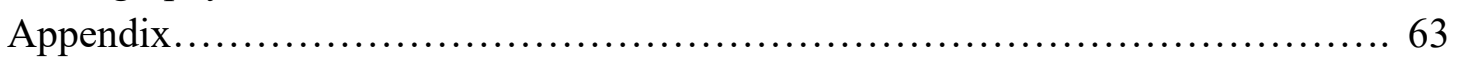

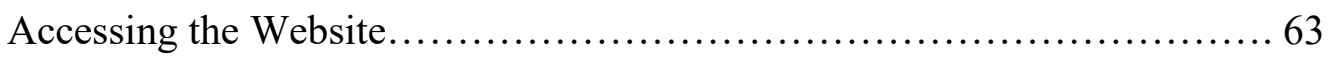

Manuscript Reading (Ms spelling) transcription with Cantus IDs............. 64 


\section{List of Tables}

Table

Page

1. Quires of the Carleton Antiphonary .............................. 8

2. Fragments and Manuscript Waste in the Carleton Antiphonary......... 17

3. Initials in the Carleton Antiphonary............................ 25

4. Rubricated abbreviations in the Carleton Antiphonary................ 26

5. Structure of the Carleton Antiphonary......................... 35

6. List of Feast Days in the hymnal............................... 38

7. Abbreviations for the hypertext edition of the Carleton Antiphonary... 49 


\section{List of Figures}

Figure

Page

1. Guideword in primary bookhand, in black ink on folio $8 \mathrm{v} \ldots \ldots \ldots \ldots \ldots \ldots$

2. The spine of the Carleton Antiphonal.................................... 7

3. F.28v - 29r, uneven edges where the parchment was cut................ 9

4. F.61v $-62 \mathrm{r}$, jagged edges from cut with scissors.......................9

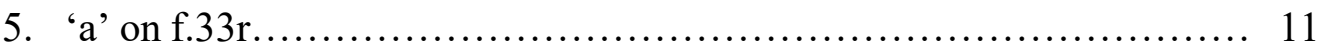

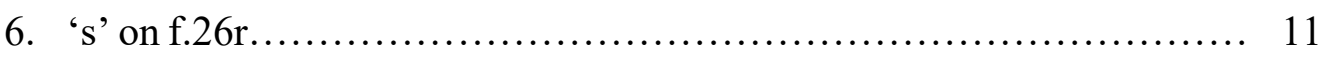

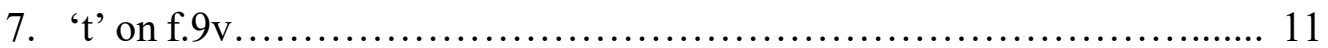

8. Single compartment ' $a$ ', f.42v ..................................... 12

9. Tironian 'et' with flourish, f.43r................................ 12

10. A comparison of the 'a' letterforms from Bookhand 1 and Bookhand 4... 13

11. Marginal annotation, guidewords on f.6v ............................ 14

12. Marginal annotation, additional musical notation on $\mathrm{f} .30 \mathrm{v} \ldots \ldots \ldots \ldots \ldots . .14$

13. Guideword and paried rubrication from folio $44 \mathrm{r} \ldots \ldots \ldots \ldots \ldots \ldots \ldots \ldots \ldots \ldots$

14. Bottom margin of f.37r.......................................... 16

15. Exterior margin of f.39r....................................... 16

16. Example of in-text musical notation through rubrication on f.63r....... 25

17. A naturally occurring hole in the parchment........................ 27

18. f.13r showing water damage causing the ink to bleed................. 28

19. Showing various damages.......................................... 29

20. f. 37r. Added musical notes by early modern hand.................... 43

21. f.28r "Audivi vocem de caelo dicentem mihi" ......................... 43

22. f. $27 \mathrm{v}$ with pencil annotations reading "animas tuas".................. 44 


\section{Introduction}

In the European tradition, medieval manuscripts are hand-made objects, such as codices and scrolls, completed during the Middle Ages (roughly fifth - sixteenth century CE). These objects are often illuminated (hand-painted in metallic paints of gold and silver) and feature art within their margins as decorations. Others are more simple, using only black (or dark brown) and red inks for the text and structure with little or no decoration.

Medieval manuscripts had less diversity of contents than the modern literary repertoire. Charters, religious texts, and philosophical works (Plato and Aristotle being popular topics) were among the most common genres of medieval manuscripts. Of the religious manuscripts, the most common were within the Christian tradition but Judaic and Islamic codices were also circulated in Europe.

Because each medieval manuscript is handmade and handwritten, each is distinct in both material and structure, as well as content. Digitizing often means that two dimensional images are generated as a means to reproduce them. Unfortunately, digitization means that there are inevitably aspects of the physical object which are missing in the digital format (spatial evidence, touch, and even sound or smell). However, reproducing manuscripts digitally can be more faithful to their original nature than a printed edition. Medieval liturgical manuscripts are naturally hypertextual because each line represents a connection to another manuscript or memorized text from which the manuscript draws or copies. However, the relationship between manuscripts and the language of liturgy has now been lost. That is why manuscripts need to be contextualised in a larger body of works that would have been common knowledge to the monk. In other words, culturally ingrained knowledge of the liturgy formed many layers of understanding in the medieval mind that can be reproduced best 
in a non-linear, hypertext format. This way, information can be accessed ad hoc and can be as general or thorough as the need demands. ${ }^{1}$

Although it is clear that our understanding of medieval artefacts can be deepened by the digital format, it is also important to consider how the digital turn changes how people interact with manuscripts. Importantly, I have found that the tools I have used to produce the interactive transcription (from digital camera to Transkribus) have shaped the outcome of the digitization and therefore influences how the end user will perceive and interact with the manuscript. Notably, because I did not have access to a large format scanner, a digital camera was used to produce the images hosted on the website. This has created consistency issues in both lighting and sizing. Still, many humanists encourage the digital turn. In fact, a major essay collection on the topic, Meeting the Medieval in a Digital World, published in 2018, compels scholars to see themselves as not only medievalists, humanists, etc. but as digital humanists also. The work outlines exciting and novel ways to interact with manuscripts using digital tools and the final chapter even acts as a roadmap for scholars hoping to bridge the gap between their own disciplines and the digital realm. ${ }^{2}$

The manuscript that is digitally reproduced here is Ottawa, Carleton University Library, Archives and Research Collection MS. 1 (referred to as the Carleton Antiphonary). Like all medieval manuscripts it is distinct in both material and structure, as well as content. It is a compound manuscript i.e. containing two or more previously separate manuscripts that are bound together in a modern binding. My palaeographical analysis reveals that it has four distinct book hands and has been passed between several

\footnotetext{
${ }^{1}$ Capelli, Roberta. "Practical and Theoretical Implications of Digitizing the Middle Ages" CLCWeb: Comparative Literature and Culture 15.3 (2013): <https://doi.org/10.7771/14814374.2248>

2 Davis, Matthew Evan, Turnator, Ece, and Mahoney-Steel, Tamsyn, eds. Meeting the Medieval in a Digital World. Amsterdam: Arc Humanities Press, 2018.
} 
different owners. The primary manuscript $(\mathrm{f} .1 \mathrm{r}-61 \mathrm{v})$ is consistent with an Iberian latefifteenth/early sixteenth century provenance and the secondary manuscript (f.62r $-64 v$ ) corresponds with fourteenth century Gothic Quadrata manuscripts copied in southern Europe. This we know thanks to comparison with digital reproductions of other Iberian manuscripts online, which allows us to study the palaeography of manuscripts and understand their relationship to one another in time and place. Finally, the isolated final leaf (f.65r $-65 \mathrm{v})$ is likely a later addition to the composite manuscript and is compatible with southern European rotunda manuscripts.

Both manuscripts are incomplete texts taken from Christian liturgical manuscripts which features plainchant, religious songs that are meant to be sung by a choir, usually without accompanying music. The first manuscript, which will be referred to as part A, includes a tonary, followed by sections from the canonical hours (or liturgy of the hours): the office of the dead and various feasts days. This manuscript is termed the Antiphonary because it is largely a collection of antiphons, short chants that draw their lyrics from the Psalms. These were commonly found in monastic settings since choir books featuring antiphons were integral to the daily monastic ritual. This part was created for practical and pedagogical use by its Franciscan owners. The book demonstrates long-standing use as it has been repaired continuously. However, the second manuscript (part B) is a hymnal, demonstrating a clear distinction from part A.

There are no accession records about the entry of the manuscript into Carleton's Archive and Research Collection (ARC), but a donation plate added to the interior binding suggests that the manuscript may have been donated to St. Patrick's College before its dissolution in 1973 at which time the library was amalgamated with 
Carleton's. There are no records to indicate its provenance prior to this time, so we must depend on physical evidence to indicate the provenance for the manuscript.

Carleton's ARC has been collecting manuscript fragments for teaching purposes since the 1960s. ARC also has a second liturgical chant manuscript in its holdings (Ms.2) as well as eleven additional medieval documents including leaves from Books of Hours and bibles, and two English charters. 


\section{Chapter 1: Physical Description of Ms.1}

The Carleton Antiphonary is a codex which is composed of two manuscripts bound together, with a distinct final page appended to the end. The codex is made up of 65 folios (130 pages). The text is copied in a single column of six lines in black ink with six corresponding four-line staves in red ink, with the exception of the final page where 5-line staves appear. There are no page numbers present on either of the manuscripts nor the final page. The primary manuscript or part A (f.1r $-61 \mathrm{v})$ is consistent with an Iberian late-fifteenth/early sixteenth century provenance. The second, much smaller manuscript, part B (f.63r - 64v) corresponds with 14th century gothic quadrata manuscripts copied in southern Europe. The Carleton Antiphonary also features a curiously distinct final page $(65 \mathrm{r}-65 \mathrm{v})$ which may be the result of a different scribe or could be from another separate manuscript, and is compatible with southern european rotunda manuscripts. The following physical description therefore is divided into three parts: part A and part B and the final page which is dealt with separately from the two larger parts for clarity.

\subsection{Mise-en-page and Pagination}

Part A (Primary manuscript)

The first and largest manuscript that makes up the Carleton Antiphonary ranges from f.1r $-61 \mathrm{v}$ (133 folios). The folios have a height of $382 \mathrm{~mm}$ and a width of 286 $\mathrm{mm} .^{3}$ The text is copied in a single column of six lines with six corresponding four-line staves. ${ }^{4}$ The margins are $31 \mathrm{~mm}$ wide on the interior margin and $54 \mathrm{~mm}$ on the outer.

\footnotetext{
${ }^{3}$ Folios from the first quire (esp. f. $2 r$ as it has little wear on the pages) were referenced as the standard sample for measurements.

${ }^{4}$ Without access to the manuscript due to COVID-19 closures, correct measurements for the staves cannot be taken at this time.
} 
The height from the top of the page to the top of the first line of music is $21 \mathrm{~mm}$ and 86 $\mathrm{mm}$ from the bottom of the final line of text to the bottom of the page. Some slight variation exists when the folios have been worn down or cropped. There are no page numbers present on either of the manuscripts. There is a single guideword in the primary bookhand present throughout the manuscript found in part $\mathrm{A}$ on folio $8 \mathrm{v}$ (Figure 1). This folio marks the end of the first quire.

But there are several guidewords found in the margins in a lighter, brown, ink, discussed in more detail below.

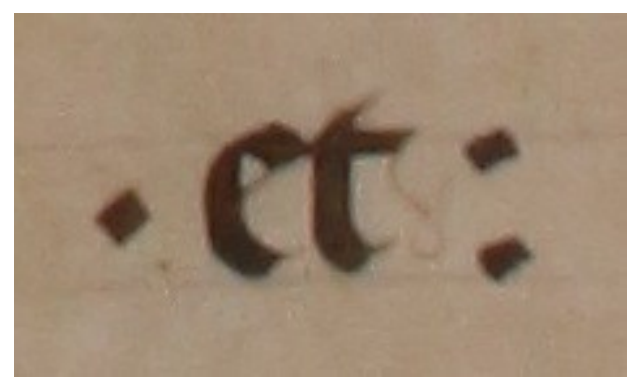

(Figure 1: catchword in primary bookhand, black ink on folio 8v)

Part B (Secondary manuscript)

Folios $63 r-65 v$ differ from the standard layout of part A. The leaves are slightly smaller than part A - roughly $281 \mathrm{~mm}$ in width and $378 \mathrm{~mm}$ in height. Unlike the very uniform Part A, the folios of part B show slight variations between 2 and $6 \mathrm{~mm}$ difference in height and width. Folio $63 \mathrm{r}-64 \mathrm{v}$ features slanted lines for musical notation, a difference of $4 \mathrm{~mm}$ from one end to the other. This is an indication that this manuscript may be earlier than part A, copied at a time when lines were drawn by hand or after drypoint ruling rather than by plummet (leadpoint) ruling, which left visible lines on the page. 
Final page

Curiously, the final leaf (f.65r - 65v) features five-line staves which are not present at any other point in the manuscript (other than on the later added manuscript fragments used for repairs or annotation, discussed below). ${ }^{5}$

\subsection{Binding and Quires}

The binding is currently deteriorating. The front cover and initial quire detached as a result of use in 2017. It is unclear when the manuscripts were rebound together to create the compound manuscript but perhaps a more in-depth study of the binding method and materials used could provide clarity. It is a leather-wrapped cardboard binding with a cotton fabric added to reinforce the spine of the manuscript (Figure 3 ).

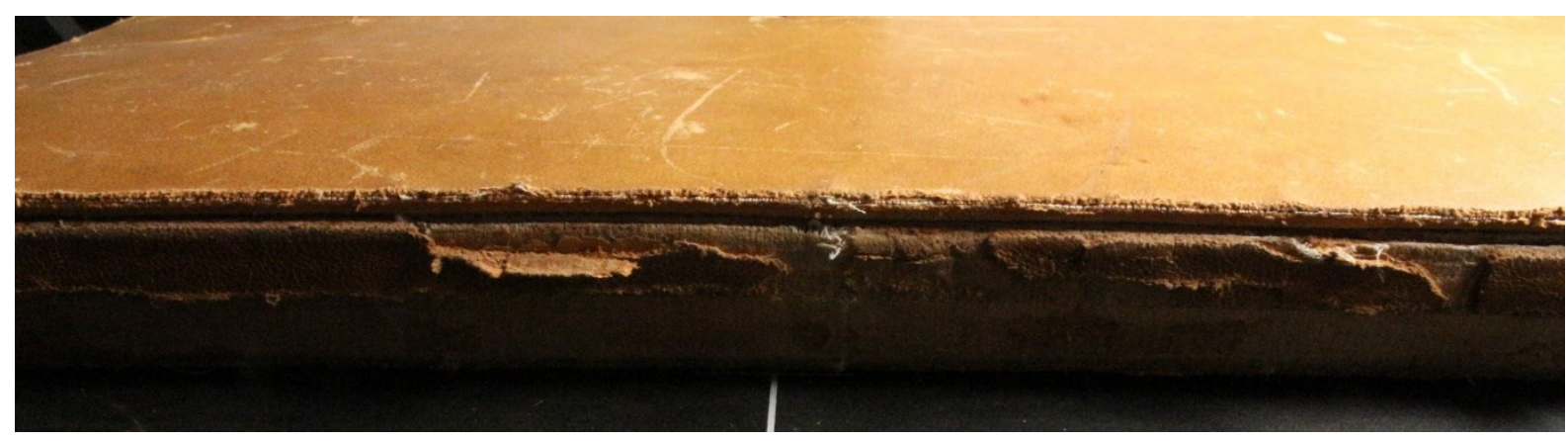

(Figure 2: The spine of the Carleton Antiphonal)

The Carleton Antiphonary is composed of ten quires comprised of eight folios each, except where pages have been removed. See the following table:

\footnotetext{
${ }^{5}$ Again, without access to the manuscript due to COVID-19 closures, correct measurements for this final page cannot be taken at this time.
} 
Table 1: Quires

Part A

\begin{tabular}{|l|l|l|}
\hline Quire no. (in order) & No. of folios in quire & Folio range \\
\hline 1 & 8 & $1 \mathrm{r}-8 \mathrm{v}$ \\
\hline 2 & 8 & $9 \mathrm{r}-16 \mathrm{v}$ \\
\hline 3 & 8 & $17 \mathrm{r}-24 \mathrm{v}$ \\
\hline 4 & 7 & $25 \mathrm{r}-31 \mathrm{v}$ \\
\hline 5 & 8 & $32 \mathrm{r}-38 \mathrm{v}$ \\
\hline 6 & 8 & $39 \mathrm{r}-46 \mathrm{v}$ \\
\hline 7 & 8 & $47 \mathrm{r}-54 \mathrm{v}$ \\
\hline 8 & 7 & $55 \mathrm{r}-61 \mathrm{v}$ \\
\hline
\end{tabular}

Part B

\begin{tabular}{|l|l|l|}
\hline Quire no. (in order) & No. of folios in quire & Folio range \\
\hline 1 & 3 & $62 \mathrm{r}-64 \mathrm{v}$ \\
\hline
\end{tabular}

Final Page

\begin{tabular}{|l|l|l|}
\hline Quire no. (in order) & No. of folios in quire & Folio range \\
\hline 1 & 1 & $65 \mathrm{r}-65 \mathrm{v}$ \\
\hline
\end{tabular}

This results in a total number of 65 folios throughout ten quires. Therefore, there are a total of fifteen missing or removed pages, if we assume a standard 8-folio quire. Quire 4 has two removed leaves from the current binding (between f.28v-29r), cut out which have left imprecise edges (Figure 3). Quire 5 has a missing page which was removed prior to current binding (between f.33v - 34r.). Quire 8, the final quire of part A (between f.61v - 62r) has its final leaf removed with a jagged cut from scissors (figure 4). Quire 9, or part B, has had its final five leaves removed prior to the current binding (between $64 \mathrm{v}-65 \mathrm{r}$ ). Finally, quire 10 is a standalone leaf (and therefore missing seven leaves) which is likely a distinct leaf sourced from a separate manuscript which has 
been appended to the end of the Carleton Antiphonary, which will be discussed more fully below.

Carleton University does not have any of the removed leaves in its holdings.

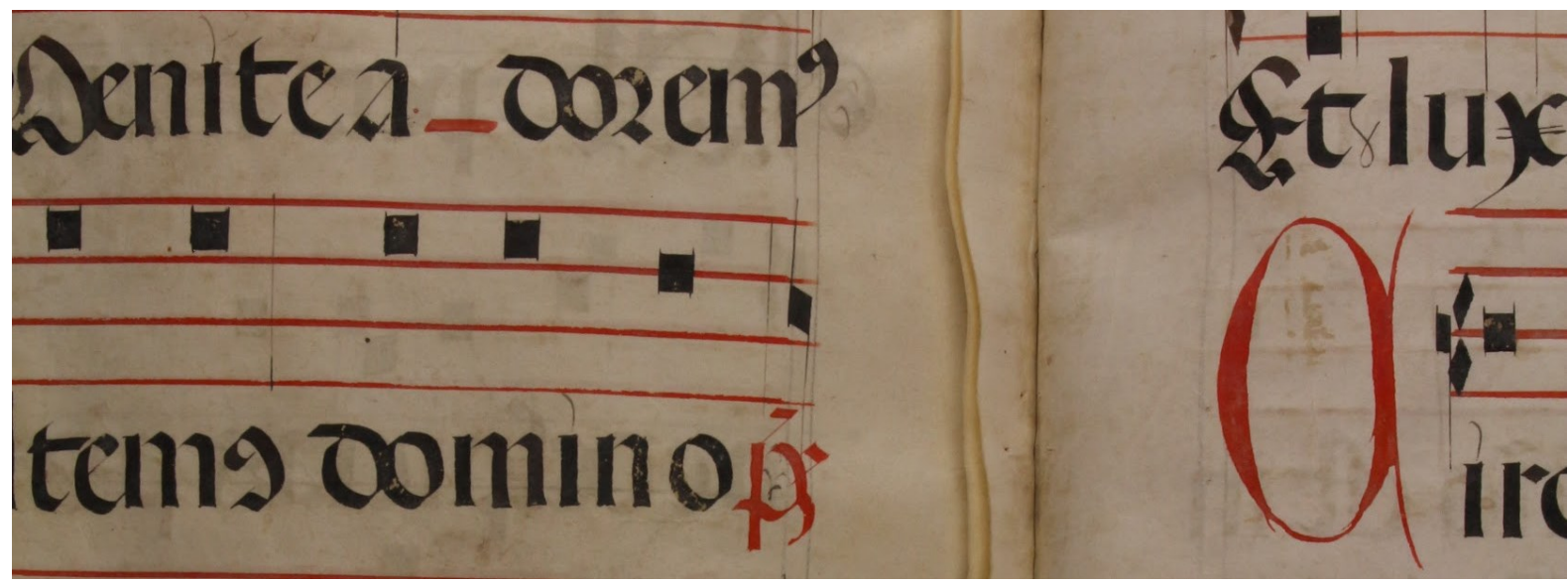

(Figure 3:f.28v - 29r, uneven edges where the parchment was cut)

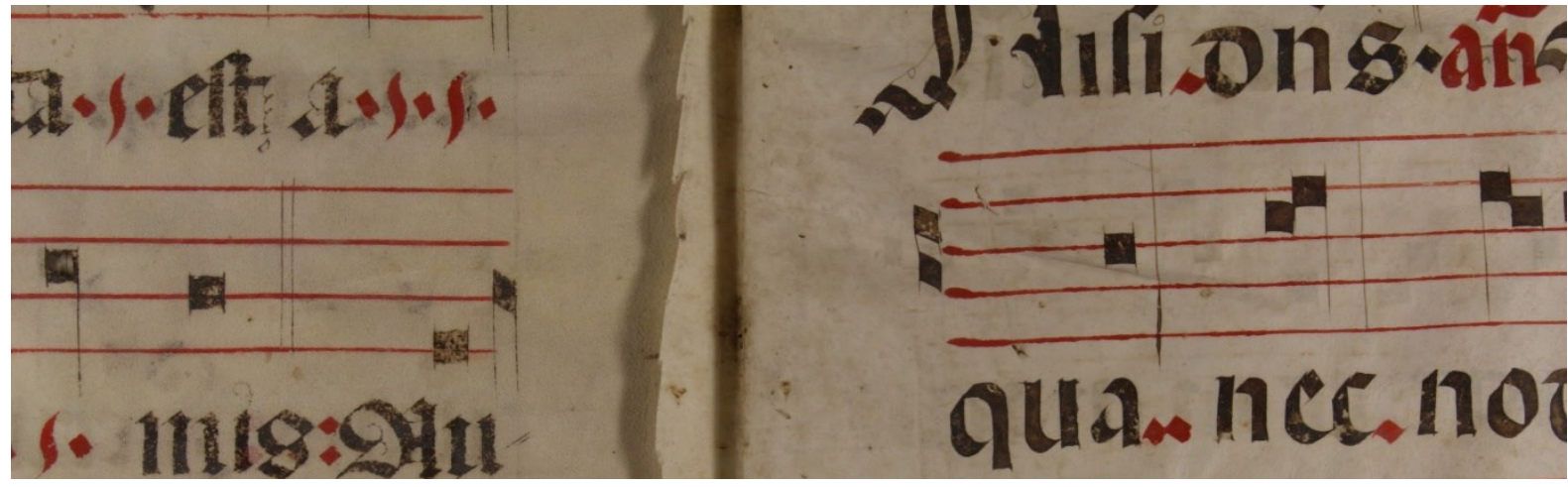

(Figure 4: f.61v-62r, jagged edges from where the parchment was cut with scissors)

\subsection{Palaeography (Scribal Hands) and Ink}

The Carleton Antiphonary features four distinct bookhands. The main bookhand (bookhand 1) is a Spanish Rotunda script from the fifteenth century. The second bookhand (bookhand 2) appears to be a Humanist script, copied much later onto the original parchment. Both are found in Part A of the manuscript. The third bookhand (bookhand 3) appears on manuscript part B (the manuscript appended to the end of the 
main manuscript) and is an early form (likely fourteenth century) of Southern Textualis, a script found in southern Europe.

The final leaf (f. $65 \mathrm{r}-65 \mathrm{v}$ ) presents bookhand 4, a Rotunda script featuring very rounded letterforms. Although we see differences between scribal hands in the Bookhand 1 in primary manuscript, this bookhand presents a significant departure from those letterforms. The rubrication is also distinct, with added features to accompany five-line staves, which are also unique to the final leaf. It will be treated separately from the primary bookhand for these reasons.

Additionally, at least one early modern and one modern script can be found in the margins and in line with the text of the manuscript.

Bookhand 1 (f. 1r - 42r; 44r - 61v)

The first and most widely used bookhand in the codex, this bookhand is an example of fifteenth-century Southern Textualis (Rotunda). It features uniquely Spanish characteristics such as:

- The 'a' which closes its upper lobe with a spiralling hairline. (Figure 5)

- The usage of 'et' in full. Italian Rotunda features the Tironian 'et'. In Spain, these fusions were rarely used. This manuscript features no Tironian 'et' in the Rotunda Book Hand.

- The lobed 's' done in two strokes, sometimes barely or only partially connected, is characteristic of southern European book hands. (Figure 6)

This bookhand helps us date part A of the manuscript as we see similarities in letterforms and aesthetics of Spanish chant manuscripts from 1501-1600 (see plates 1- 
5). Furthermore, during the fourteenth century onward Iberian scribes often included characteristic decorative hairlines on the final letter of important words which can be seen throughout the first bookhand (Figure 7). ${ }^{6}$ This palaeographical evidence suggests that this part of the manuscript (part A) was copied after the mid fifteenth but certainly by the mid-sixteenth century.

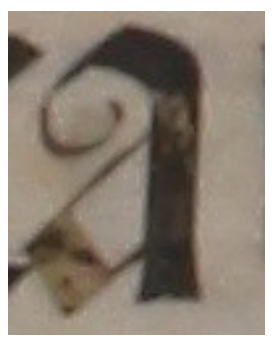

(figure 5: f.33r)

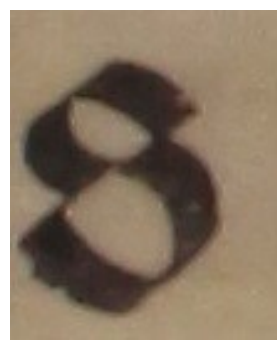

(figure 6: f.26r)

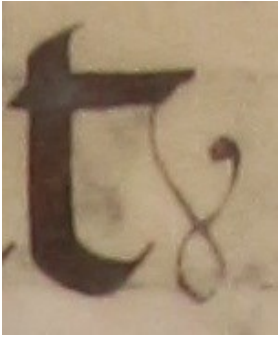

(figure 7: f.9v)

Bookhand 2 (f. 42r - 43r)

The second bookhand is a half-cursiva (hybrida) script. This hand is clearly a later and less polished addition to the manuscript. Bookhand 1 ends the text halfway through f. 42r, but lined the musical staves on folios 42r - 43v. Bookhand 2 adds the text and music from the Kyrie to these existing staves. The dark brown ink and the irregular letter forms show a marked difference from Bookhand 1. The scribe seems unpractised in comparison to the professional and very regular letterforms of both bookhands 1 and 3. The single-compartment 'a' (Figure 8) and a somewhat triangular form with a pointed top indicates it as a Hybrida script. The script was developed in the mid-sixteenth century as a result of a growing middle class need for a faster script than textualis. ${ }^{7}$ The addition of a fifth staff line in the musical notation, as well as the use of

\footnotetext{
${ }^{6}$ Derolez, Albert. The Palaeography of Gothic Manuscript Books: from the Twelfth to the Early Sixteenth Century. Cambridge: Cambridge University Press, 2012. p.114.

${ }^{7}$ Knight, Stan "Section 24: The Roman Alphabet" in The World's Writing Systems. Daniel, Petter T. and Bright, Williams (eds.) New York: Oxford University Press, 1996. p.324.
} 
the later Tirontian 'et' (Figure 9), demonstrates that this script was added to the original manuscript leaves some time after the original script was copied.

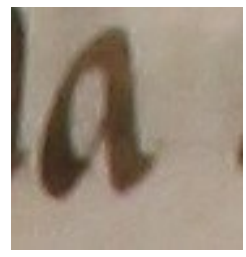

(Figure 8: single-compartment ' $a$ ', f.42v)

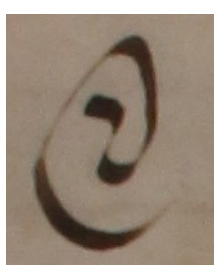

(Figure 9: tironian 'et' with

flourish, f.43r)

Bookhand 3 (f. 62r - 64v)

The third bookhand is found in part B of the codex which the codicological evidence suggests is a separate manuscript bound together with Part A at a later date (see binding). It is a form of southern textualis with distinct differences to Bookhand 1. It is much more angular than the Rotunda, and each letter is created using multiple pen strokes to create gothic minimums. It is likely a less formal form of Gothic Quadrata, as minims are present but often inconsistent. ${ }^{8}$

Bookhand 4 (f.65r - 65v)

Bookhand 4 is another Rotunda script with features that make it distinct from the Rotunda script from Bookhand 1. The letterforms are thicker, less angular, and shorter than the Rotunda of Bookhand 1. Although Bookhand 1 features multiple different forms of the letter ' $a$ ' but each follows a particular style (Figure 10.2-3)

\footnotetext{
${ }^{8}$ Knight, Stan "Section 24: The Roman Alphabet" in The World's Writing Systems. Daniel, Petter T. and Bright, Williams (eds.) New York: Oxford University Press, 1996. p.322.
} 
Bookhand 4 features an 'a' that is unlike that of the typical Spanish Rotunda form (Figure 10.4). This difference is more clear when compared to Spanish Rotunda scripts from around the same date (Plates 1 - 4).

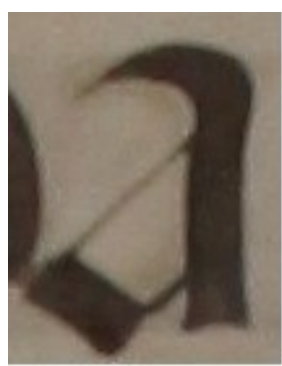

1

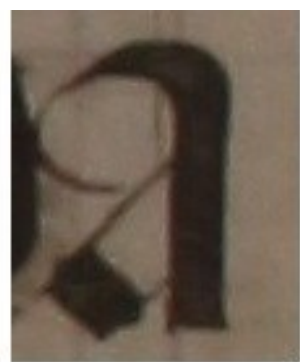

.2

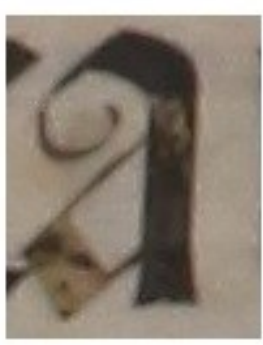

.3

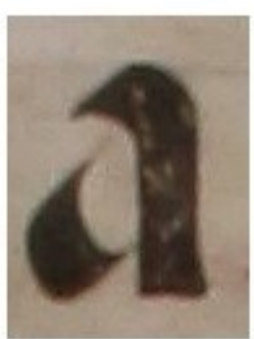

.4

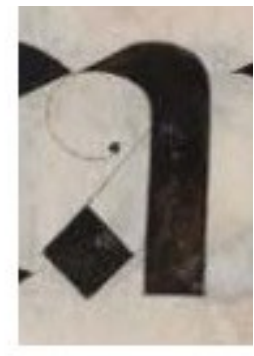

Plate 1

(Figure 10: a comparison of the 'a' letterforms from Bookhand 1 (.1-.3) and

Bookhand 4 (.4) From left to right: sourced from Carleton Antiphonary folios 2v, 2v,

$33 r$, and 65r. Sourced from "Benedicamus Domino y vísperas de santos" ${ }^{\text {"9 }}$.1r)

In fact, it is likely that this final leaf was copied at a different time, likely later than Bookhand 1 or Bookhand 3 (an angular southern textualis) which precedes it in the manuscript. If this script is connected to Bookhand 1, this could be the result of a different scribe and rubricator, but the inclusion of five-line staves, a departure in musical style (inclusion of melismatic notes) and the fact that early modern collectors often replaced the final leaf of manuscripts with less damaged leaves to make the manuscript appear more complete, reinforce the idea that this leaf came from a separate manuscript. ${ }^{10}$

1.4 Corrections and Annotations

Contemporary Annotations (f.3v, 6v, 12v, 21v 28r, 30v, 44r, 45r)

9 Biblioteca Nacional de España, Biblioteca Digital Hispanica, MPCANT/1. Fol 1r. (Plate 1)

${ }^{10}$ Clemens, Raymond, and Timothy Graham. Introduction to Manuscript Studies. Ithaca:

Cornell University, 2007. p.112. 
A few small marginal notes can be found in the early half of part A of the compound manuscript. These are likely guidewords as they appear alongside the heading of each new mode of the tonary (between $3 v-21 v$ ) and are not written in the same black ink as the bookhands, but a lighter brown ink. The small size of the text suggests a very fine writing tool was used to add the text to the parchment (figure 11). In some places, the marginal notes may have been cut off during binding or perhaps were never added.

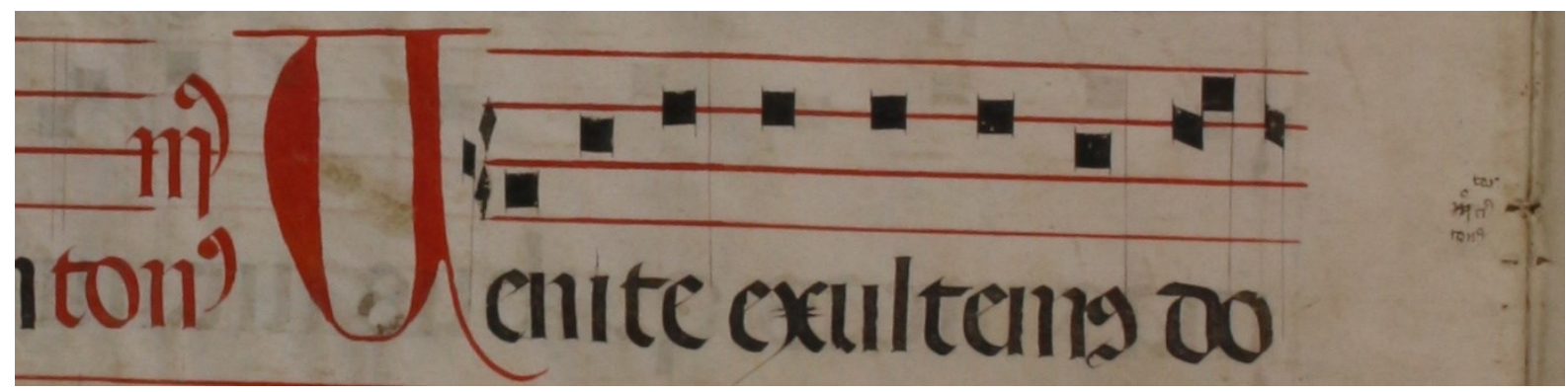

(Figure 11: marginal annotation, guidewords on f.6v)

Another contemporary annotation was the addition of a three-line stave and what appears to be an alternate musical notation for the Kyrie. This can be found in the bottom margin of $f .30 \mathrm{v}$ and is meant to blend in somewhat with the rest of the page (Figure 12).

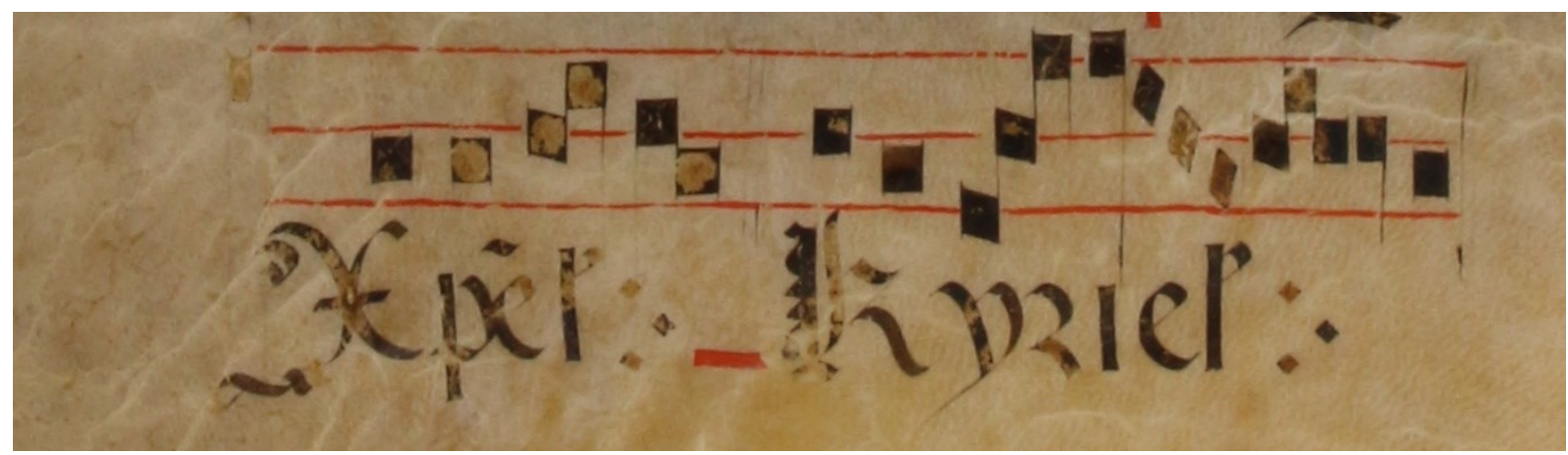

(Figure 12: marginal annotation, additional musical notation on f.30v) 
Similar marginal guidewords (as those found in the tonary) appear again on f.44r and 45r. Again, these correspond with headings. These annotations are paired with the rubricated headings "Sabbato in aduentum domini. Hymnus" (figure 13), "ad nona" (both found on f.44r) and "in epiphania domini" (f.45r).

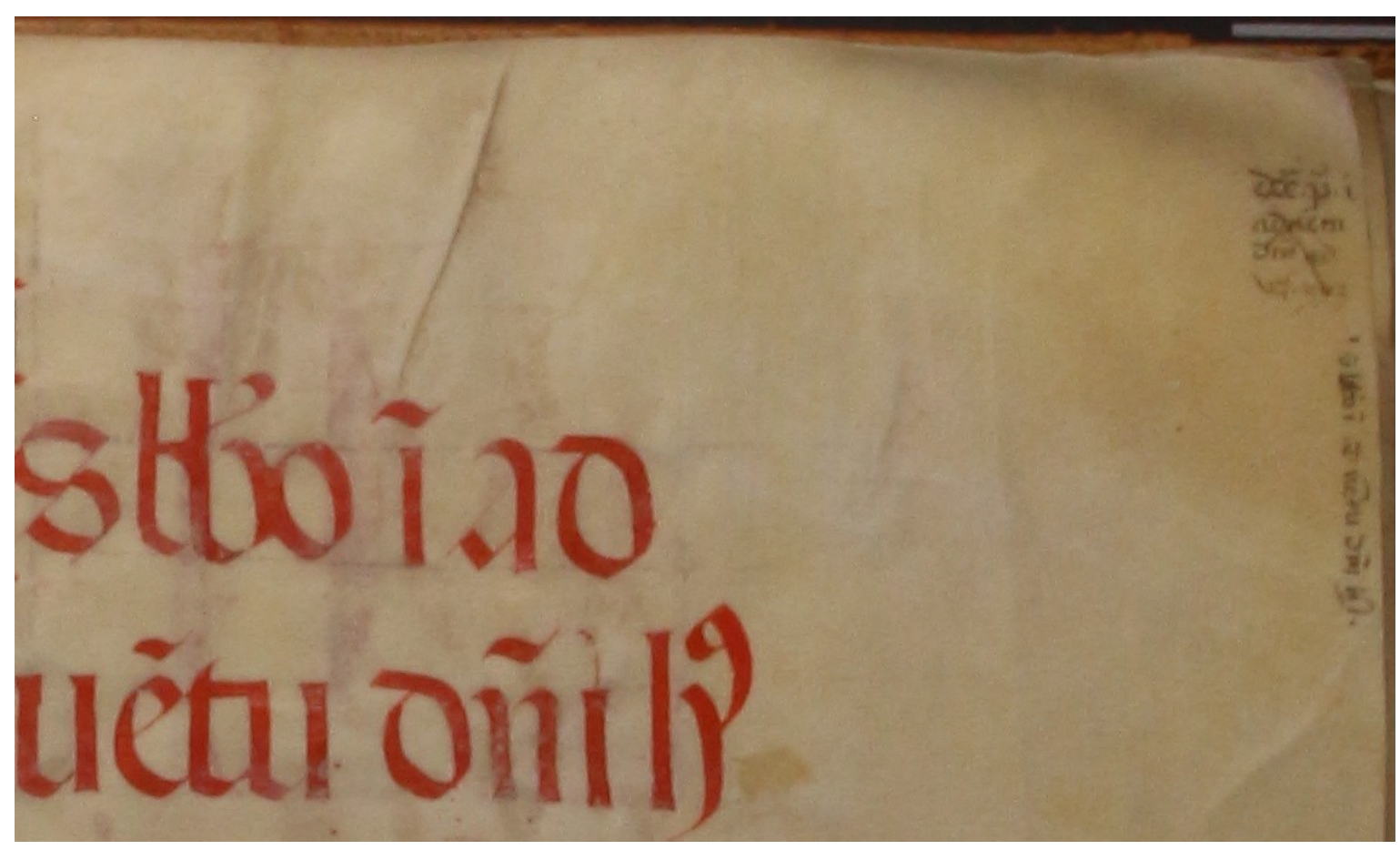

(figure 13: guideword and paired rubrication from folio 44r)

Early Modern Annotations (f.37r, 39r)

Written in the same pen as the Bookhand 2, the early modern (hybrida) script found between f. $42 \mathrm{r}-43 \mathrm{r}$, these annotations were interested in expanding upon the music as well as the text. The kyrie eleison was expanded on f.37r (figure 14) and a single line of music and corresponding chant was added to 39r. The annotation of biblios, although appearing to be an attempt to expand or correct the text could not be found in other instances of the Office of Dead (figure 15). 


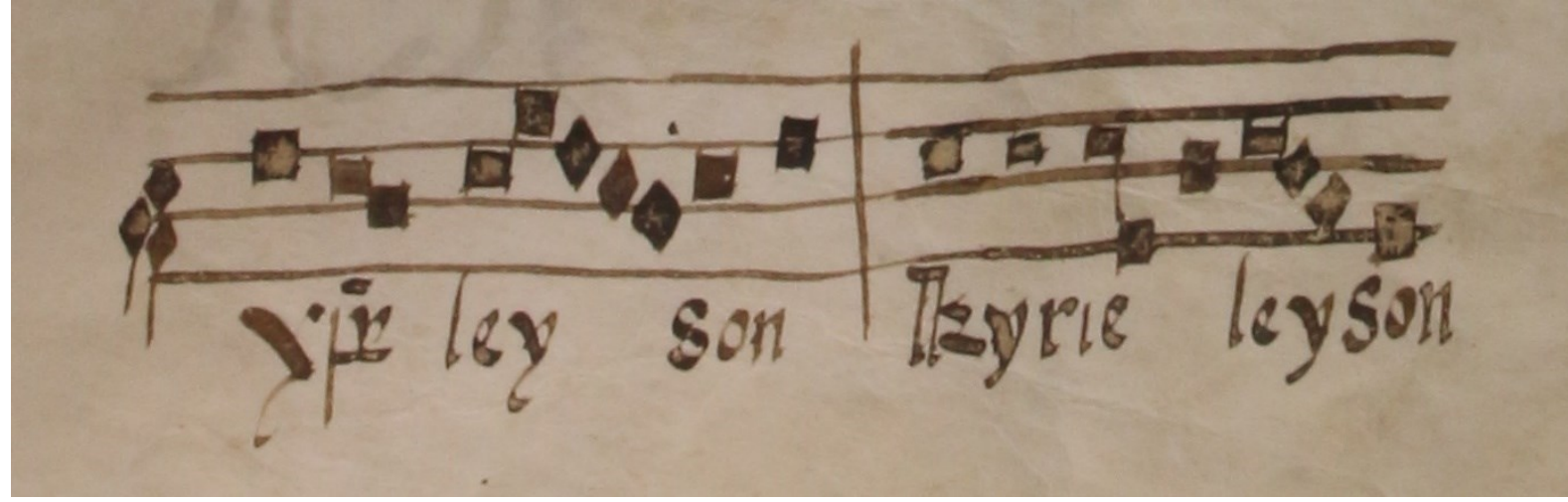

(Figure 14: bottom margin off.37r)

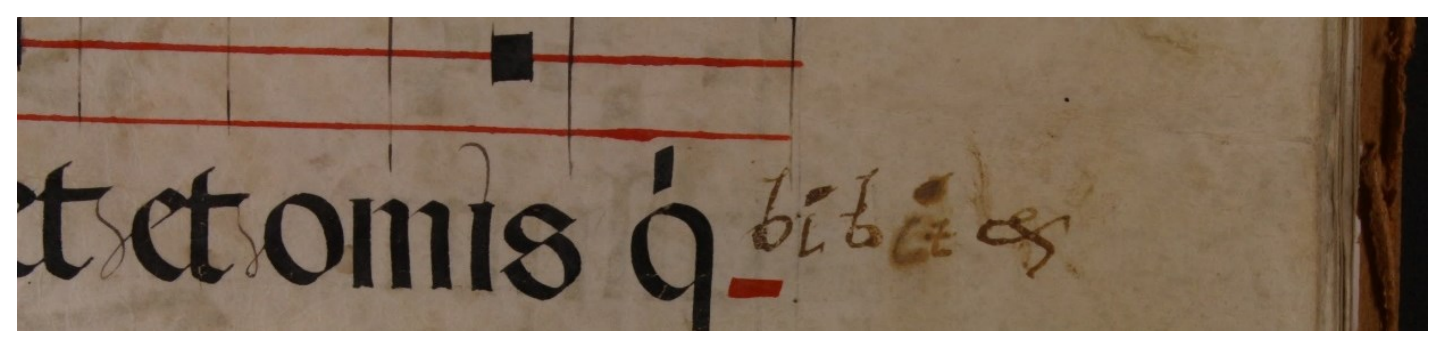

(Figure 15: exterior margin of f.39r)

Modern Annotations (27r, 27v, 28r, 34v)

The modern annotations, likely from the twentieth century found on $\mathrm{f} .27 \mathrm{r}-28 \mathrm{r}$ are written with a lead pencil in a modern cursive script. These annotations are meant to expand abbreviations or make corrections but are often incorrect. For example, “animum tua3" is written as "animus tuas" (f.27v).

Interestingly, on f.34v although also a modern script, attempts to imitate the rotunda script. The annotator has written the correction on a blank piece of manuscript with a dull brown ink and glued the annotation on top of the original script.

\subsection{Fragments}

The Antiphonary, in addition to being the product of multiple manuscripts for the main book, also has many repairs that were made using manuscript fragments. It is 
common to see reinforcements and repairs of the holes and damages in this manuscript done with manuscript waste, which are pieces of parchment from liturgical texts deemed outdated. ${ }^{11}$

Table 2: Fragments and Manuscript waste in the Carleton Antiphonary

*Please note that all fragments have been reoriented to be more legible.

\begin{tabular}{|c|c|}
\hline Image & Information \\
\hline (Fragment 1: detail, f.4r) & $\begin{array}{l}\text { Script: Rotunda. Uses black, red, and blue } \\
\text { ink. } \\
\text { Method: Sewn. } \\
\text { Text: } \\
\text { This fragment is from another liturgical } \\
\text { book copied in Rotunda script. According to } \\
\text { an } 1851 \text { book containing the complete } \\
\text { Office Hours, the text is from the third } \\
\text { nocturne of Holy Thursday, to be recited } \\
\text { after psalm } 108 \text { and prior to the } 7 \text { th reading } \\
\text { (Corinthians } 11: 17-11: 22) .{ }^{12} \\
\text { Origin: } \\
\text { The use of blue, a more expensive pigment } \\
\text { than red, suggests a slightly wealthier place } \\
\text { of origin than the monastery that copied } \\
\text { Ms.1.13 }\end{array}$ \\
\hline (Fragment 2: f.4v) & $\begin{array}{l}\text { Script: Rotunda. Uses blue ink. } \\
\text { Method: Sewn. } \\
\text { Text: } \\
\text { This fragment is from another liturgical } \\
\text { manuscript. Likely from the feast of } \\
\text { Christmas Eve: "Ex Sion species decoris } \\
\text { ejus. Judaea et Jerusalem nolite". }{ }^{14} \\
\text { Origin: } \\
\text { The use of blue, a more expensive pigment } \\
\text { than red, suggests a slightly wealthier place } \\
\text { of origin than the monastery that copied }\end{array}$ \\
\hline
\end{tabular}

\footnotetext{
${ }^{11}$ Clemens, Raymond, and Timothy Graham. Introduction to Manuscript Studies. Ithaca: Cornell University, 2007. p.109.

12 Eucologe dédié à Marie, ou Heures Nouvelles du Diocèse de Lyon, contenant Les Offices Complets, accompagnés du plain-chant. La Guillotiere: J.M. Bajat Père, Fils et c. 1851. p. 295 - 298.

${ }^{13}$ Clemens, Raymond, and Timothy Graham. Introduction to Manuscript Studies. Ithaca: Cornell University, 2007.p.31.

${ }^{14}$ Cantus ID: 003511
} 


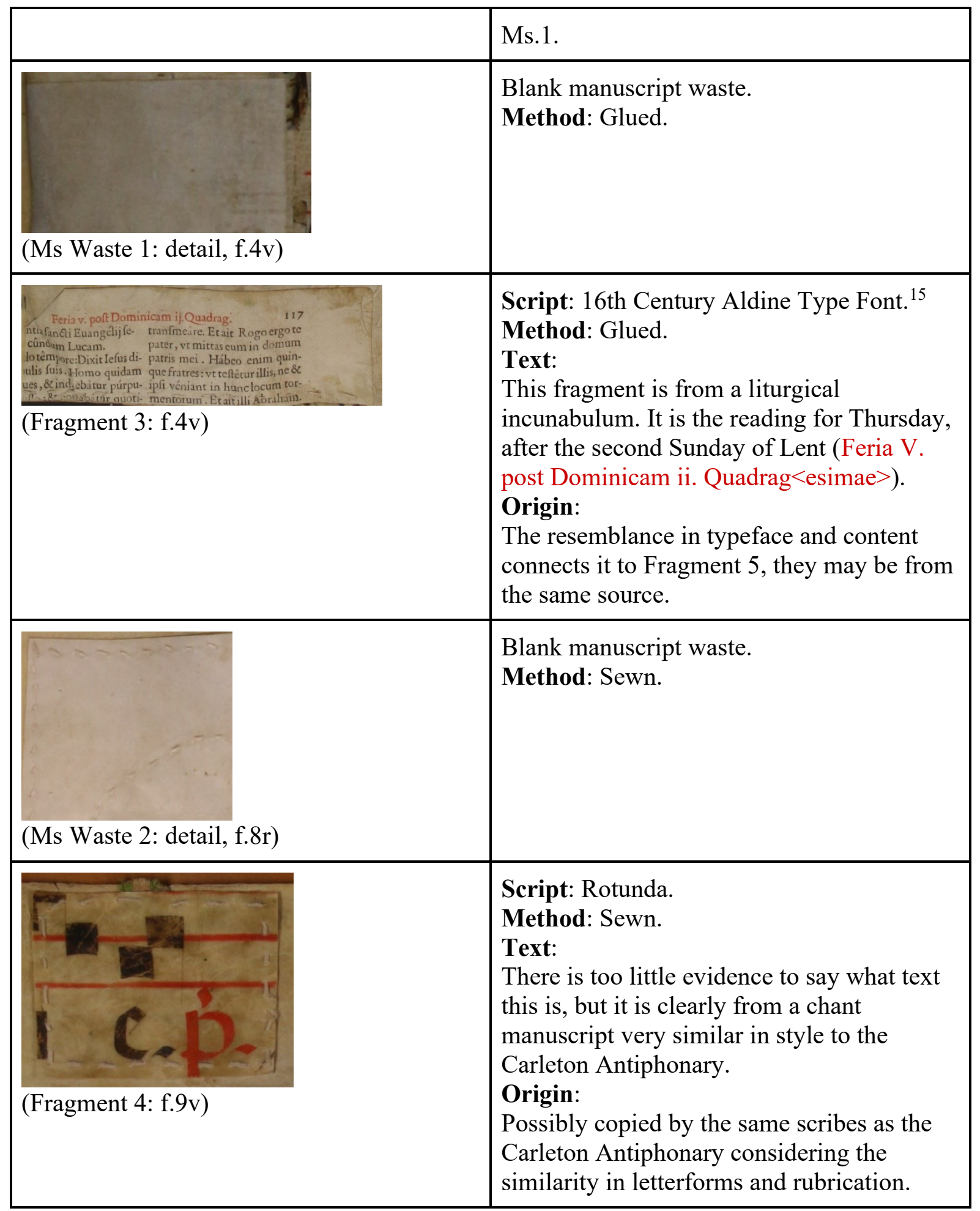

\footnotetext{
${ }^{15}$ Boardley, John. 2016. "The Firs Roman Fonts." I Love Typography. Accessed April 10, 2020. .http://ilovetypography.com/2016/04/18/the-first-roman-fonts/
} 


\begin{tabular}{|c|c|}
\hline (Ms Waste 3: f.10r) & $\begin{array}{l}\text { Blank manuscript waste. } \\
\text { Method: Sewn. }\end{array}$ \\
\hline 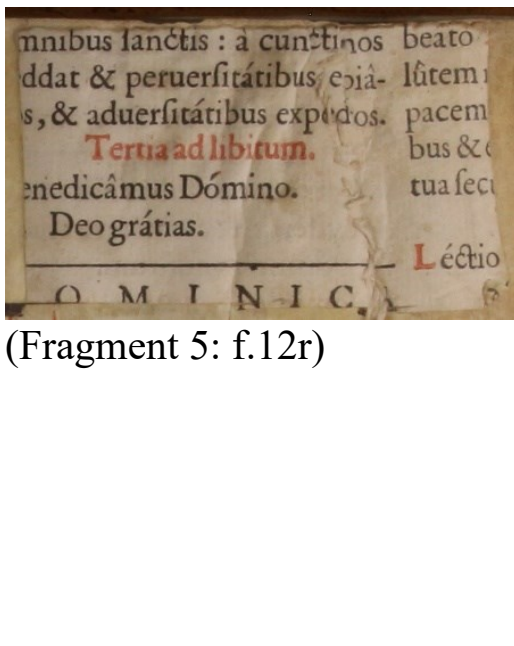 & $\begin{array}{l}\text { Script: } 16 \text { th Century Aldine Type Font. } \\
\text { Method: Sewn and glued. } \\
\text { Text: } \\
\text { This fragment is from a liturgical } \\
\text { incunabulum. It is a reading for the } 5 \text { th } \\
\text { Sunday after Epiphany according to the } \\
1885 \text { Eucologe romain. "...omnibus Sanctis } \\
\text { à cunctis nos reddat et peruersitatibus } \\
\text { expiatos et aduersitatibus expeditos." } \\
\text { Origin: } \\
\text { The resemblance in typeface and content } \\
\text { connects it to Fragment } 3 \text {, they may be from } \\
\text { the same source. }\end{array}$ \\
\hline (Fragment 6: f.15r) & $\begin{array}{l}\text { Script: Rotunda. } \\
\text { Method: Sewn. } \\
\text { Text: } \\
\text { A snippet of Exodus } 15: 11 \text { "quis similis tui } \\
\text { in fortibus Domine quis similis tui } \\
\text { magnificus in sanctitate terribilis atque } \\
\text { laudabilis et faciens mirabilia". A common } \\
\text { reading during Holy Tuesday, at laudes. } \\
\text { Origin: } \\
\text { The hairlines on the 'a's' suggests a Spanish } \\
\text { or Italian origin. The use of the tironian et } \\
\text { (7) suggests it was copied by a different } \\
\text { scribe than that of the Carleton Antiphonary, } \\
\text { as the symbol is not used in the primary } \\
\text { bookhand of the manuscript. }\end{array}$ \\
\hline
\end{tabular}

${ }^{16}$ Eucologe Romain: A L'Usage Des Collèges, 17th edition. Librairie de Poussielgue Frères: 1885. p.121.

${ }^{17}$ Eucologe Romain: A L'Usage Des Collèges, 17th edition. Librairie de Poussielgue Frères: 1885. p.195 


\begin{tabular}{|c|c|}
\hline (Fragment 7: detail, f.17v) & $\begin{array}{l}\text { Script: Rotunda. } \\
\text { Method: Sewn. } \\
\text { Text: } \\
\text { There is not enough textual information to } \\
\text { know the larger context. } \\
\text { Origin: } \\
\text { The rounded hairline 'a' and Rotunda form } \\
\text { suggest a Spanish origin. It is written in a } \\
\text { more informal hand, as seen in the } \\
\text { extremely rounded 'd' and elongated } \\
\text { Rotunda ' } \mathrm{m} \text { '. }{ }^{18}\end{array}$ \\
\hline & $\begin{array}{l}\text { Blank manuscript waste. } \\
\text { Method: Sewn. }\end{array}$ \\
\hline 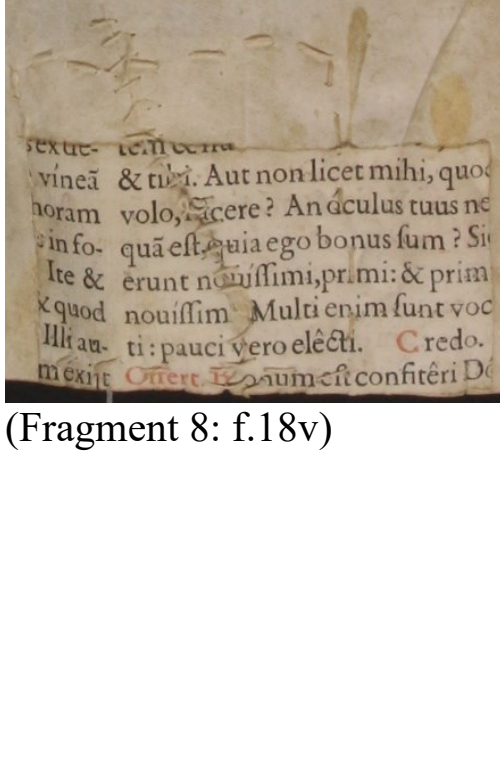 & $\begin{array}{l}\text { Script: 16th Century Aldine Type Font. } \\
\text { Method: Glued. } \\
\text { Text: } \\
\text { This fragment is from a liturgical } \\
\text { incunabulum. It is a reading for } \\
\text { Septuagesima Sunday. }{ }^{19} \text { Matthew } 20: 14 \text { - } \\
20: 16 \text { "sicut et tibi aut non licet mihi quod } \\
\text { volo facere an oculus tuus nequam est quia } \\
\text { ego bonus sum sic erunt novissimi primi et } \\
\text { primi novissimi multi sunt enim vocati pauci } \\
\text { vero electi" Followed by the Credo and } \\
\text { Bonum est confiteri. }{ }^{20} \\
\text { Origin: } \\
\text { The resemblance in typeface and content } \\
\text { connects it to Fragment } 3 \text { and } 5 \text {, they may } \\
\text { be from the same source. }\end{array}$ \\
\hline
\end{tabular}

${ }^{18}$ Derolez, Albert. The Palaeography of Gothic Manuscript Books: from the Twelfth of the Early

Sixteenth Century. Cambridge: Cambridge University Press, 2012. p.114.

${ }^{19}$ Eucologe Romain: A L'Usage Des Collèges, 17th edition. Librairie de Poussielgue Frères: 1885. p.124.

${ }^{20}$ Cantus ID: g00638. 


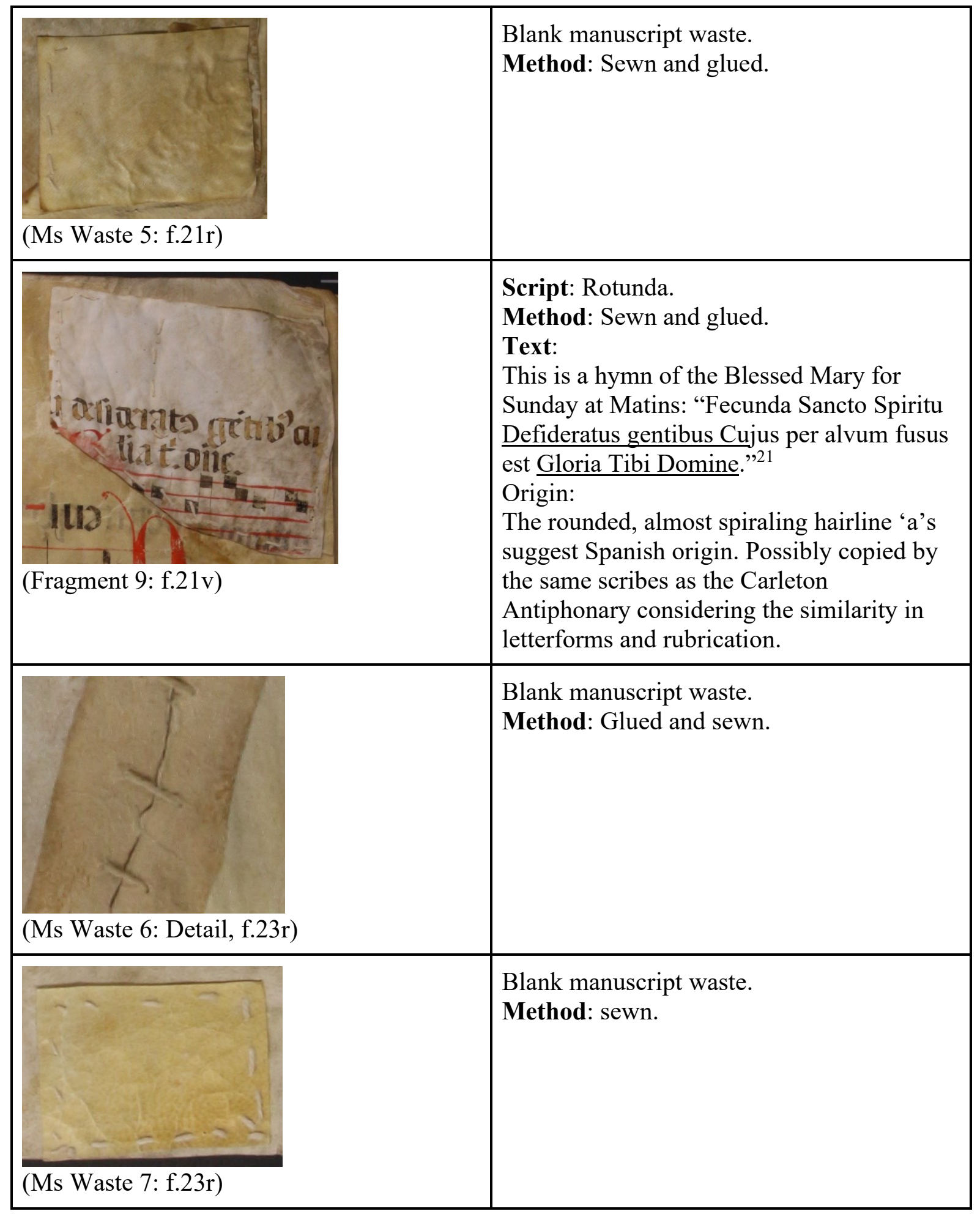

${ }^{21}$ Chambers, John David. The Psalter, or Seven Ordinary Hours of Prayers, London: J. Masters and Co. 1852. p.30. 


\begin{tabular}{|c|c|}
\hline $\begin{array}{l}\text { Dominicain Septuage fima. } \\
\text { inda } 8 \text { cercia dem efcam ff } \\
\text { rificationis vf- uêrunt, \&tor } \\
\text { i. Cinerum ex- fpiritâlemb } \\
\text { hon eft Duplex: tem defpiri } \\
\text { (Fragment 10: Detail, f.23v) }\end{array}$ & $\begin{array}{l}\text { Script: 16th Century Aldine Type Font. } \\
\text { Method: Glued. } \\
\text { Text: This fragment is from a liturgical } \\
\text { incunabulum. The heading "Dominica in } \\
\text { Septuagesima" is the ninth Sunday before } \\
\text { Easter. The rubrication on the left provides } \\
\text { instructions for performance before and after } \\
\text { the Festo Purificationis (February 2) On the } \\
\text { right, in black: "Moyse baptizati sunt in } \\
\text { nube et in mari et omnes eamdem escam } \\
\text { spiritalem manducaverunt et omnes eumdem } \\
\text { potum spiritalem biberunt bibebant autem de } \\
\text { spiritali Consequente eos petrà petra autem } \\
\text { erat Christus"22 } \\
\text { Origin: } \\
\text { The resemblance in typeface and content } \\
\text { connects it to Fragment } 3,5 \text { and } 8 \text {. They } \\
\text { may be from the same source. It is further } \\
\text { connected to fragment } 8 \text { both are from } \\
\text { Septuagesima Sunday. }\end{array}$ \\
\hline (Fragment 11: f.24r) & $\begin{array}{l}\text { Script: Rotunda. } \\
\text { Method: Sewn. } \\
\text { Text: There is too little evidence to } \\
\text { determine the text. } \\
\text { Origin: This script has more Italian features } \\
\text { than Iberian, such as the po fusion which } \\
\text { have overlapping strokes. }{ }^{23} \text { This fusion is } \\
\text { not present in Bookhand } 1 \text { but is Bookhand } \\
3 \text { (an angular southern textualis). }\end{array}$ \\
\hline (Fragment 12: detail, f.24v) & $\begin{array}{l}\text { Script: Rotunda. } \\
\text { Method: Sewn. } \\
\text { Text: From psalm 118:90-93: "In } \\
\text { generationem et generationem veritas tua } \\
\text { fundasti terram et permanet Ordinatione tua } \\
\text { perseverat dies quoniam omnia serviunt tibi } \\
\text { Nisi quod lex tua meditatio mea est tunc } \\
\text { forte perissem in humilitate mea In } \\
\text { aeternum non obliviscar iustificationes tuas } \\
\text { quia in ipsis vivificasti me". This is } \\
\text { prominently used in the "Seven psalms of }\end{array}$ \\
\hline
\end{tabular}

${ }^{22}$ Eucologe Romain: A L'Usage Des Collèges, 17th edition. Librairie de Poussielgue Frères: 1885. p.123.

${ }^{23}$ Derolez, Albert. The Palaeography of Gothic Manuscript Books: from the Twelfth of the Early Sixteenth Century. Cambridge: Cambridge University Press, 2012. p.108-9 


\begin{tabular}{|l|l|}
\hline & $\begin{array}{l}\text { Penitence"24 } \\
\text { Origin: The hairline 'a' suggests iberian } \\
\text { origins. This script appears to be more } \\
\text { formal than Bookhand 1. We find a very } \\
\text { close match in script with Fragment } 6 .\end{array}$ \\
\hline & $\begin{array}{l}\text { Script: Southern Textualis. } \\
\text { Method: sewn. } \\
\text { Text: There is too little evidence to } \\
\text { determine the text. } \\
\text { Origin: There is too little evidence to } \\
\text { determine the origin for certain, but the } \\
\text { angular elongated 's' and 'o' forms suggest } \\
\text { southern textualis, perhaps Italian or French. }\end{array}$ \\
\hline (Fragment 13: f.30v) & $\begin{array}{l}\text { Blank manuscript waste. } \\
\text { Method: Sewn. }\end{array}$ \\
\hline (Ms Waste 8: f.31r) & \\
\hline
\end{tabular}

\subsection{Initials and Rubrication}

This codex, like most medieval manuscripts, uses a system of capital letters and initials, rubricated or not, to signify different textual elements. Two types of initial letters (sometimes called drop capitals because they often take up the space of two lines instead of one) exist in this manuscript, the rubricated initial and the plain initial (copied in the same ink as the rest of the manuscript text). Capital letters exist in two forms as well, partially rubricated and a plain capital. In many liturgical manuscripts such as antiphonals rubricated abbreviations, such as $p s$ for psalm, also signifies a new textual element. See table 4 for details.

${ }^{24}$ Eucologe Romain: A L'Usage Des Collèges, 17th edition. Librairie de Poussielgue Frères: 1885. p.433-435. 


\section{Tonary}

In the tonary, each of the eight modes, indicated by a rubricated heading, start with a rubricated initial. These rubricated initials or drop capitals are flush with the baseline of the text but take up the space of an entire stave or sometimes go a bit beyond it. The next is a plain initial, which is always preceded by a rubricated abbreviation such as $\mathrm{X}$ (verse). The third and final level is the plain capital which marks the beginning of a new sentence within a verse.

\section{Antiphonary}

The antiphonary follows a similar structure to the tonary with a few key additions. Each major heading starts with a rubricated initial (drop capital) that is flush with the baseline of the text but takes up the space of an entire stave or sometimes goes a bit beyond it. Antiphons, signified by a rubricated $a$ with an extended crossline, are directly followed by a plain initial. Psalms (rubricated $p s$ or sometimes $\bar{p}$ ) however, are only followed by a plain capital, placing them within the hierarchy of the antiphon.

Hymnal

Each major heading, indicated by a rubricated heading of the hymnal, starts with a rubricated initial. A plain initial is used to begin the final refrain of the hymn. Interestingly, the hymnal does not use white space, but instead employs rubricated symbols between syllable units to indicate melisma as evident by the quick succession of notes that typically appear above it (figure 16). 


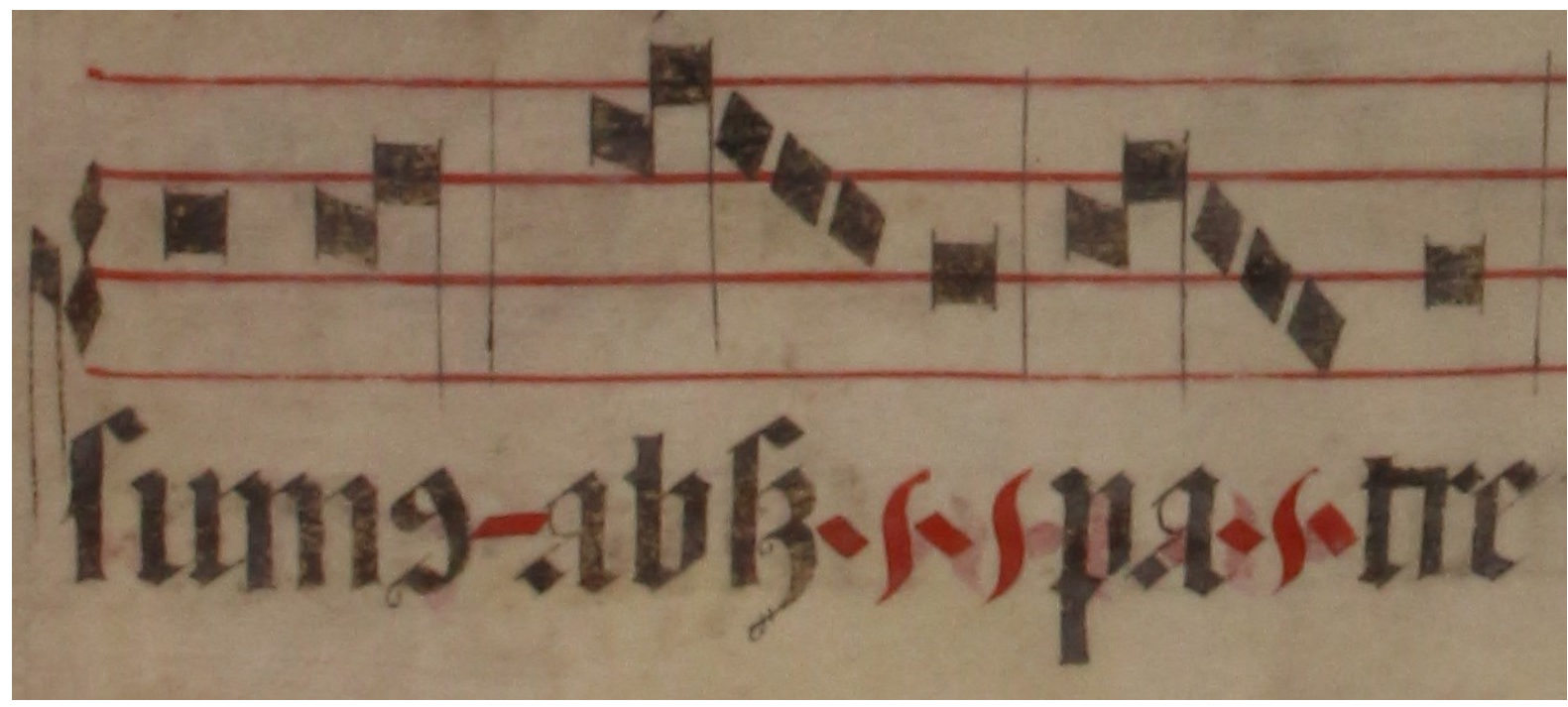

(Figure 16: example of in-text musical notation through rubrication on f.63r. Note the melismatic notation on patre)

Final Leaf (Antiphonal)

Antiphons, signified by a rubricated $a \bar{n}$, are directly followed by a plain initial.

Psalms (rubricated $\overline{p s}$ ) are also followed by a plain initial.

Table 3: Initials from the Carleton Antiphonary

\begin{tabular}{|l|l|l|l|}
\hline Rubricated Initial & Quartus tonus Uenite \\
\hline Plain Initial & & & \\
& & & \\
& &
\end{tabular}




\begin{tabular}{|l|l|l|}
\hline Plain capital & Venite \\
\hline Partially rubricated capital & f.10v & \\
\hline & f.12v & $\mathrm{Si}<$ cut $>$ \\
\hline
\end{tabular}

Table 4: Table of Rubricated abbreviations from the Carleton Antiphonary

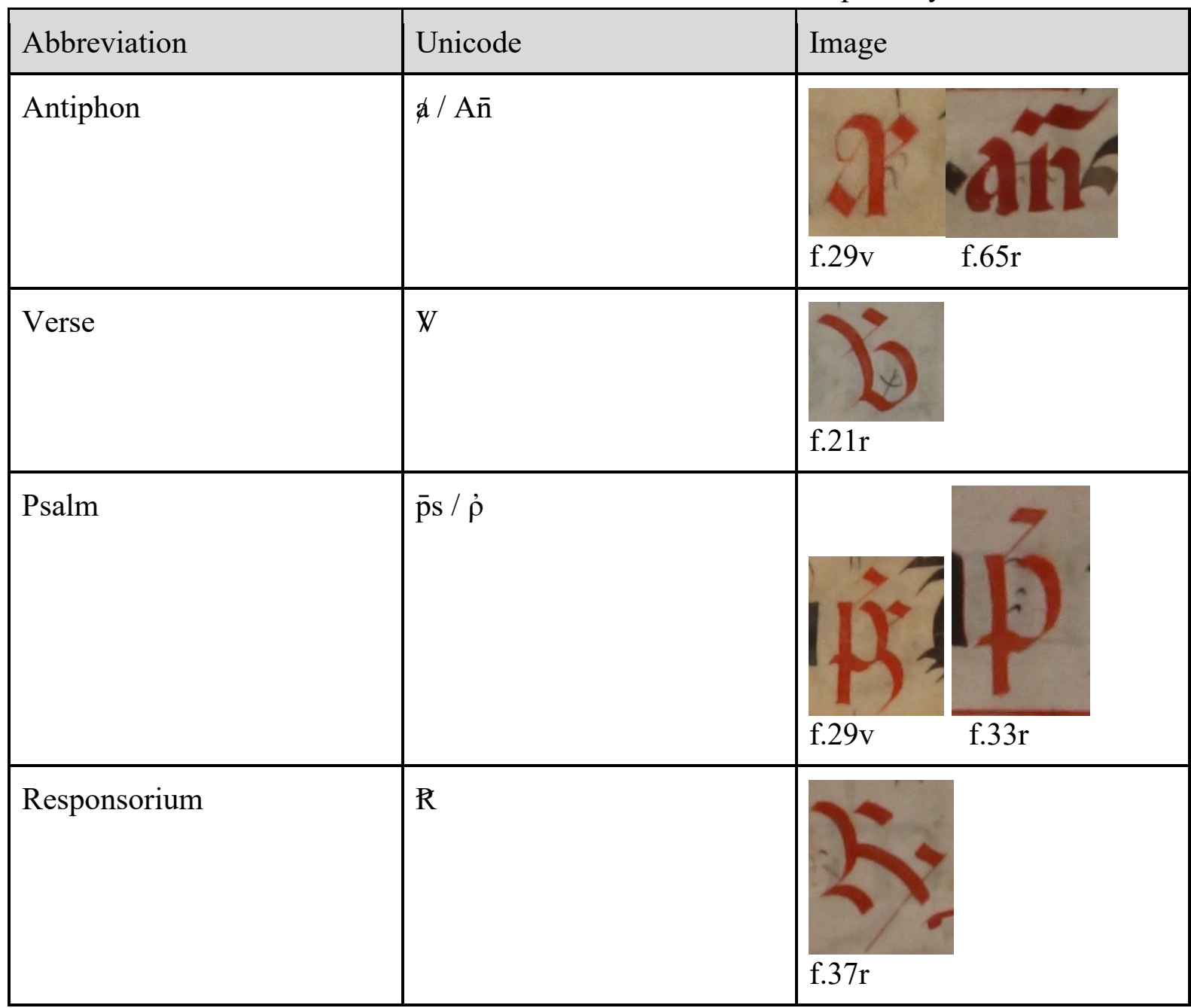

\subsection{Writing Support}

The parchment has many physical attributes from the animal itself including naturally occurring holes (figure 17) which indicates that this codex's usage was likely practical rather than for display or for a wealthy patron. Furthermore, the manuscript 
demonstrates considerable wear as a result of extended use such as stains, ink and liquid damage, as well as minor burns. For example, the black-brown ink used on the manuscript has caused small holes to appear in the parchment. This is likely because tannic acid was used to create the ink, a compound found in many medieval inks. ${ }^{25}$

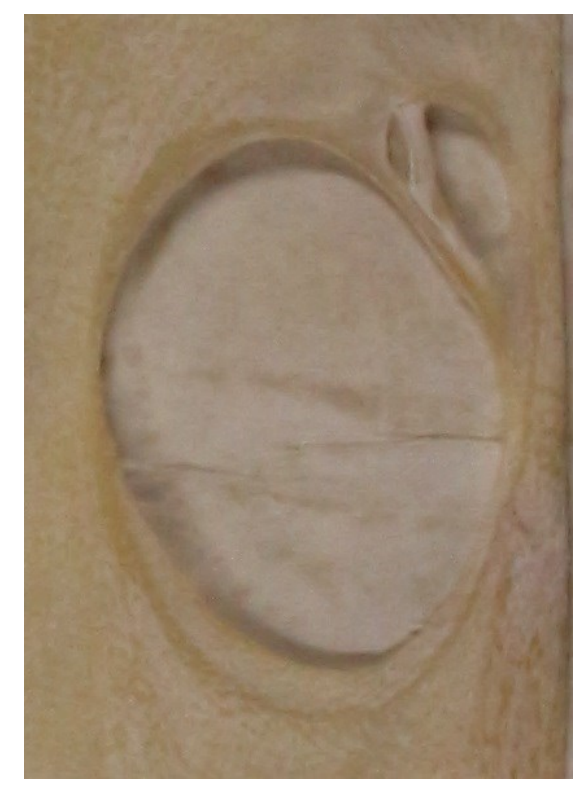

(figure 17: A naturally occurring (from the animal skin, usually sheep) hole in the parchment. This is likely from the eye of the animal.)

\subsection{Damages, Repairs and Additions}

The manuscript demonstrates long use and a long history of repairs indicating the continued use of the manuscript. Roughly eighteen leaves show signs of minor water damage. But glue damage is more common, seen on approximately twentyfour leaves of the manuscript.

Glue damages may have occurred during the many repairs done to the manuscript, especially when fragments or manuscript waste were applied to the

\footnotetext{
${ }^{25}$ Raymond Clemens and Timothy Graham, "Damaged Manuscripts" in Introduction to Manuscript Studies, (Ithaca: Cornell University, 2007) p.101.
} 
parchment. We know that the manuscript was likely in the hands of an early modern collector because of the composite nature of the manuscript. The process of unbinding and rebinding the quires to create the Carleton Antiphonary may have exposed the manuscript to glue. This is buttressed by the fact that dried pieces of glue were left on one leaf but they did not stain or stick to the leaf facing it (such as $\mathrm{f} .8 \mathrm{v}-9 \mathrm{r}$ ). Furthermore, glue damage is found on leaves that do not have fragments or manuscript waste (such as $7 \mathrm{v}$, seen in fig. 23.2) This evidence indicates that these damages occurred when the manuscript was unbound.

Folio 13r has suffered moisture damage that has resulted in the ink bleeding, strangely it does not affect the entire page equally (figure 18).

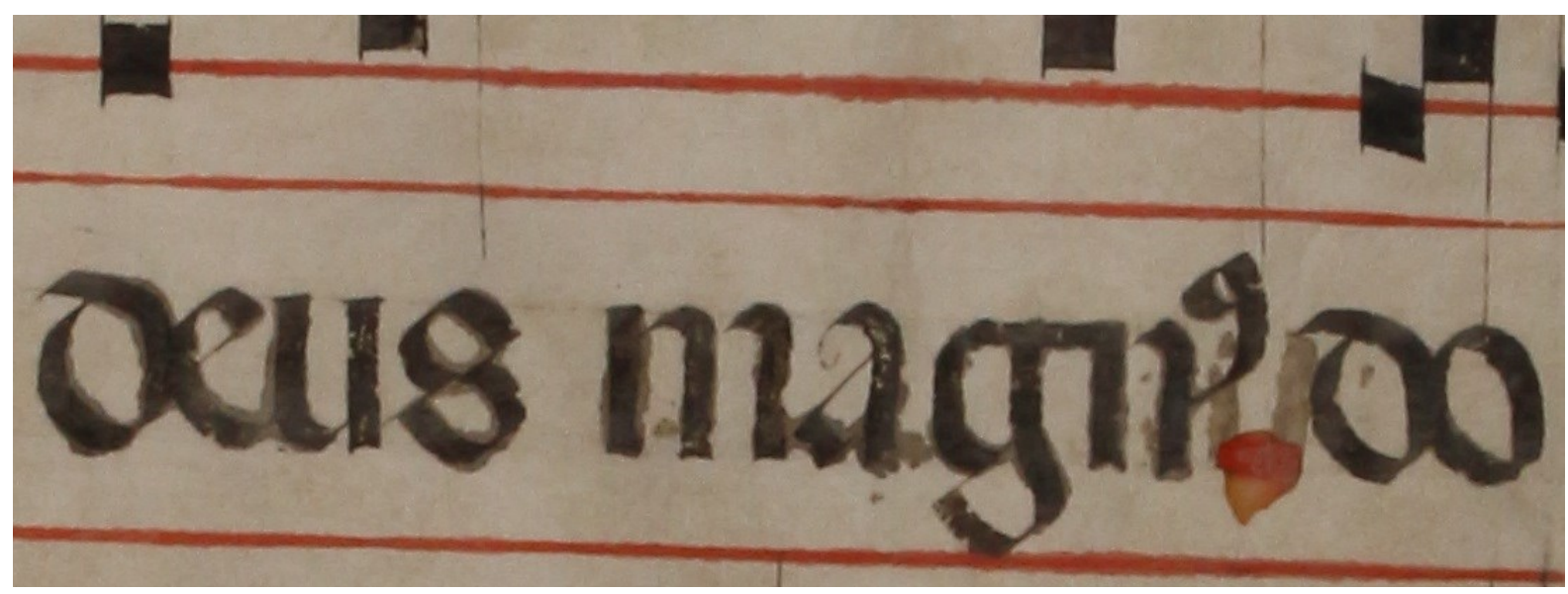

(Figure 18: f.13r showing water damage causing the ink to bleed.)

The first three leaves feature an acidic burn, possibly from a copper or iron nail that made up the original cover of the manuscript. This would have caused the acidic breakdown of the parchment over time (Figure 19.1). 

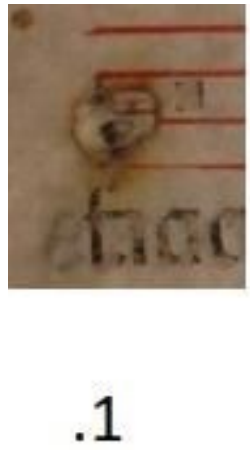
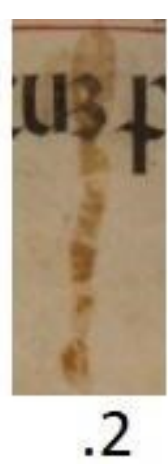
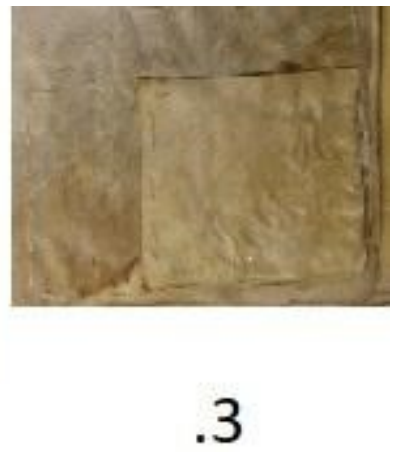

(Figure 19: From right to left: f.1r, f.7v, f.21r showing various damages.)

The leaves demonstrate extensive wear on the corners of the pages. In some cases, such as folio 21r, wear has been so extreme that the parchment had to be reinforced (Figure 19.3).

Considerable repairs are present including stitching, reinforced parchment, and rewritten text where repairs or mistakes demanded it. Twenty-two of the leaves have been reinforced with fragments (or manuscript waste) from various sources including printed materials on paper. These are typically both glued and stitched onto the original parchment. Stitching was completed by various handlers over time, evident in the range of skill and materials used to do so. Notably, reinforcements are concentrated in the first third of the manuscript, with tears left unstitched in the latter two thirds.

\subsection{Provenance}

The primary manuscript (part A) of the codex was copied in Spain in the early to mid-sixteenth century. The inclusion of prayers dedicated to the veneration of the Virgin Mary (f. 59v-60r; 61v; 65r-65v) point to Catholic monastic tradition but Franciscan origin is not impossible.

The secondary manuscript (part B) of the codex was likely copied earlier, possibly in the fifteenth century. It was copied in southern Europe, likely from Southern France 
or perhaps Italy. The earliest secure evidence of provenance comes from a type-written donation plate glued to the interior of the front cover of the manuscript, reading:

\section{4th CENTURY MANUSCRIPT}

Donated by Fr. McDougall, O.M.I.

1960

The bookplate indicates the manuscript was a gift of Father Hugh Andrew McDougall, (b. 1922, d.2012) in 1960, a member of the Oblates of Mary Immaculate (est. 1826) who was soon thereafter to become the Dean of Saint Patrick's College (from 1961-67 and again in 1973-76). This Order had a strong presence in England, Ireland and Canada, especially among the Irish Canadians in the Ottawa region. The Oblates has supported this college as a missionary venture for the order in Canada. ${ }^{26}$ MacDougall perhaps obtained the codex while completing his $\mathrm{PhD}$ (completed 1960) at Christ's College, Cambridge University. This independent Catholic college run by the Oblates of Mary Immaculate in Ottawa became a part of Carleton University in 1967. Due to financial problems, St. Patrick's College was dissolved in 1979, with its assets taken over by Carleton University, so it is likely it was at this time that the manuscript entered Carleton's collection.

Although we lack evidence to indicate when or how the codex may have left Spain or southern Europe, there are possible explanations. We know from the donation plate that the codex must have been acquired by McDougall prior to 1960. Medieval objects were often subject to theft during the wartime period and may have been

${ }^{26}$ Macdougall, H.A., St. Patrick's College (Ottawa): 1929-1979, Ottawa: Carleton University, 1982. p. 4-5. 
displaced when British soldiers returned home from the Spanish Civil War. ${ }^{27}$ It is also possible that British soldiers may have brought it to England from southern Europe after World War II if the codex was bound on the continent rather than by book sellers in the UK. ${ }^{28}$ The binding can be used to reveal when the manuscript was rebound into a composite manuscript but a more in depth study of the binding method and materials used could provide clarity.

It is now housed by Carleton University's Archives and Special Collections (ARC) when the codex was rediscovered during library renovations in the 2010s. It has not yet been digitally catalogued by the university. Courses such as The History of the Medieval Book (taught by Professor Marc Saurette) that interact with and study the codex are available to undergraduate students as of 2016.

\subsection{Conclusions}

The codicological analysis of the manuscript reveals that it is a compound manuscript featuring at least two quires of distinct origins, and at least four bookhands. The first and largest part of the codex is of Spanish origin and dates from the early to mid-sixteenth century.

It was created for practical use for the liturgy, suggested from the quality of the parchment used and the extended usage and repairs that can be observed. Possibly, it was an instructional manuscript intended to teach monks how to sing the eight modes of Gregorian chant, evident in the appended tonary (see Contents). It was further used as a teaching tool in that it was stitched and added to by amateurs, as apparent in the inconsistent quality of both later repairs and script.

\footnotetext{
${ }^{27}$ Simpson, Elizabeth (ed.), Spoils of War - World War II and Its Aftermath, (Harry N. Abrams, inc., 1997). p. 12-16.

${ }^{28}$ Ibid.
} 
The manuscript received special care by its original, likely monastic, owners. It is free of insect, rodent, or mold damage which suggests the initial owners took care to house the manuscript appropriately. The extended usage and subsequent repairs signify a position of practical, yet still great importance to the owners.

This means the codex changed hands a few times after leaving its place of origin and prior to its arrival at Carleton. The early modern and scholastic (rather than monastic) script found between $\mathrm{f}$. 42r - 43r suggests an owner in between the monastery and the bookseller. This interim owner was Spanish, as they spelled a V for a B in medieval Latin, sounds that become indistinguishable in Spanish. ${ }^{29}$

There is evidence that the codex has been rebound at least once, as it is not in its original binding. Missing pages, especially the 'clean' cuts are evidence of book breaking, likely for the purpose of resale as individual pieces of medieval art which fetch a higher price than a book sold as a whole. ${ }^{30}$ This is most often done with illuminated pages, but folia of liturgical importance would also be cut and framed for religious and collection purposes. ${ }^{31}$ The final quire was likely appended to the end of the codex, possibly by a bookseller before it was acquired by MacDougall and subsequently gifted to the university.

\footnotetext{
${ }^{29}$ Ledgeway, Adam, and Martin Maiden. The Oxford Guide to the Romance Languages. Oxford: Oxford University Press, 2016. p.388

${ }^{30}$ Gwara, Scott. Otto Ege's Manuscripts (Cayce, SC: De Brailes, 2013), 17-18.

31 Wieck, Roger S. "Folia Fugitiva" The Journal of the Walters Art Gallery, (1996), pp. 240241.
} 


\section{Chapter 2: Contents of the Manuscript}

To best understand our manuscript, and indeed to make it more accessible for study, a catalogue of its contents is necessary. Liturgical manuscripts are notoriously difficult to categorize, so I have attempted to establish the contents of this medieval book to the best of my ability. There is much to learn about the manuscript, but my intention, as I have stated, has not been to produce a critical analysis of the contents, but instead to provide a resource that will bring to light its contents to place this artefact within the broader context of its origins and history. My hope for the future is that this effort can be put towards a larger study of liturgical chant manuscripts, to better understand their structure, contents, and the lives and devotion of those who produced them.

\subsection{Genre}

The Carleton Antiphonary is made up of two distinct manuscripts (and possibly a distinct final leaf) but they can all be categorized generally as a liturgical chant. The first and largest of the two manuscripts (called part A) begins with a tonary followed by an antiphonal (a collection of antiphons, chants sung during canonical hours) for the Office of the Dead. This section is a Temporale, which features the moveable feasts, for one half of the liturgical calendar and includes major events such as Lent, Holy Week, and Easter. It is common in French and Iberian manuscripts for the hymnal, Office of the Dead, and Office of the Virgin to appear, as they do in this manuscript. ${ }^{32}$ However, the Office of the Virgin appended to the end of the codex may not be copied

\footnotetext{
32 Hughes, Andrew. Medieval Manuscripts for Mass and Office a Guide to Their Organization and Terminology. Toronto: University of Toronto Press, 1995. p.239
} 
by the scribes who first created it; this will be expanded upon in the section "Final Leaf".

After the Office of Dead the manuscript features annotations in a later cursiva script written on blank lines from the original ruling from f.42 $r-43 r$. This is an early modern annotation of the Credo (a formal statement of Christian belief) with accompanying Gregorian chant. Thereafter begins a hymnal, with hymns for a selection of feast days following the Temporal section of the liturgical calendar.

The second and much smaller manuscript (part B), which has been bound to the end of part A, are pages from the Service of Tenebrae (the last three days of Holy Week leading up to Easter Day) but it is incomplete.

But the codex's eclectic nature does not stop there. A distinct final leaf (featuring an antiphon for the Virgin Mary), and many repairs including pasted-down fragments from manuscript waste. These are all evidence of the continuous life of this codex over the last 500 years. This section will explore the liturgical contents of the Carleton Antiphonary with the goal to better understand its purpose as a devotional object, teaching tool, and medieval artefact throughout its ongoing history. 
2.2 Structure of the Codex

Table 5: Structure of Ms.1

\begin{tabular}{|c|c|c|}
\hline Distinct Manuscripts & Major Segments & Additions \\
\hline \multicolumn{3}{|c|}{ Manuscript Part A (f.1r-61v) } \\
\hline & Tonary (f.1r - 27r) & \\
\hline & $\begin{array}{l}\text { Antiphonal, Office of the Dead } \\
\text { (f. } 27 r-42 r \text { ) }\end{array}$ & \\
\hline & Blank Ruled Pages (f.42r - 43v) & \\
\hline & & The Credo (f.42r - 43r) \\
\hline & Hymnal (f. 44r - 61v) & \\
\hline \multicolumn{3}{|l|}{$\begin{array}{l}\text { Manuscript Part B (f.62r - } \\
64 v)\end{array}$} \\
\hline & Service of Tenebrae (f.62r - 64v) & \\
\hline \multicolumn{3}{|l|}{ Final Leaf (f.65r - 65v) } \\
\hline & $\begin{array}{l}\text { Antiphon for the Virgin Mary (f. } \\
65 r-65 v)\end{array}$ & \\
\hline
\end{tabular}

Manuscript part A

Tonary $(f .1 r-27 r)$

The manuscript includes a tonary appended to the beginning, preceding the antiphonal. Tonaries are a type of liturgical book that lists the eight psalm modes of gregorian chant. These modes would be used as examples to instruct monks on how to sing the various modes by memory rather than to use it continuously during chants. ${ }^{33}$ This tonary, as a memorization tool, provides evidence that this manuscript was used as a teaching tool.

\footnotetext{
${ }^{33}$ Hughes, Andrew. Medieval Manuscripts for Mass and Office a Guide to Their Organization and Terminology. Toronto: University of Toronto Press, 1995. p.114.
} 
Antiphonal, Office of the Dead (f.27r - 42r)

Directly following the tonary, the manuscript opens with an Invitatory of the Office of the Dead (Defunctorum) set at Vespers (evening prayer and the beginning of the Office Hours). The Office of the Dead is recited on the feast of All Souls (November 2) and upon the death of certain individuals. According to Andrew Hughes's useful study, Medieval Manuscripts for Mass and Office: a guide to their organization and terminology, the manuscript follows the convention of antiphonals including the basic structure of Antiphon and psalm, repeated 5 times, followed by the antiphon $A d$ Magnificat. ${ }^{34}$ The Office of the Dead has at least one folio removed between f.28v-29r. Interestingly, starting on f.42r, the parchment was left blank with only red stave lines present until the text resumed again on f.44r. These have since been filled with the Credo in an early modern hand.

The Credo (Early Modern Annotation) (f.42 r - 43r)

The blank musical staves from f.42r - 43r must have seemed the perfect place to copy the Credo onto the page to one early modern Christian. This copyist could have been a middle class Spanish person who was secular rather than monastic, judging by the early modern Cursiva script they used to pen the Credo, a script used by the growing middle class. It is not written in its entirety here, indeed the copyist has left clues of their time and context, eliminated a single line from the traditional Credo:

Et incarnatus est de Spiritu Sancto ex Maria Virgine, et homo factus est.

He was incarnate by the Holy Ghost out of the Virgin Mary, and was made man. ${ }^{35}$

\footnotetext{
${ }^{34}$ Hughes, Andrew. Medieval Manuscripts for Mass and Office a Guide to Their Organization and Terminology. Toronto: University of Toronto Press, 1995. p.242 - 244.

${ }^{35}$ Martin, Michael. "Symbolum Nicaenum", Treasury of Latin Prayers, 2016. Accessed on April 3, 2020. http://www.preces-latinae.org/thesaurus/Symbola/Nicaenum.html
} 
Although there would have to be a thorough study made to confirm the origins of this hand, one possibility is that the scribe was Spanish, and perhaps even protestant. In Catholic doctrine, the Virgin Mary is venerated and the Immaculate Conception (the notion that Mary was conceived without sin) and perpetual virginity is accepted as part of their beliefs. However, many denominations of Christianity do not venerate Mary in the same way. Most notably is the protestant movement, which gradually removed Mary from her place of key importance. ${ }^{36}$ Palaeographical evidence suggests the copyist is Spanish, owing to the fact that they replace a V for a B, sounds that become indistinguishable in Spanish. ${ }^{37}$ However, Protestantism was not adopted in Spain because of the Inquisition. Therefore, if the scribe is indeed Protestant, the text would have had to have been copied quite a bit later than the original text. It was perhaps copied sometime after the mid-seventeenth century, when Spain experienced its first (lasting) Protestant movement. However, it is more likely even later, as prosecution on a state level did not cease until after 1868, following the Glorious Revolution which brought greater religious tolerance. ${ }^{38}$ Of course, there is the distinct possibility that this copyist was a protestant of Spanish birth who fled Spain to escape inquisition. This could also explain how the manuscript initially left Spain. However, without further evidence, the religious beliefs of the scribe remain uncertain.

Hymnal (f. 44r - 61v)

One folio is left without text and only the original ruling and black staves (f.43v). Afterwards, a hymnal begins. It is not uncommon for a hymnal to be bound

\footnotetext{
${ }^{36}$ Christianson, Gerald, Bellitto, Christopher M., and Izbicki, Thomas M., eds. The Church, the Councils, and Reform : The Legacy of the Fifteenth Century. Baltimore: Catholic University of America Press, 2008. p.213

${ }^{37}$ Ledgeway, Adam, and Martin Maiden. The Oxford Guide to the Romance Languages. Oxford: Oxford University Press, 2016. p.388

${ }^{38}$ Coleman, David. "Chapter Seventeen: Spain" in The Reformation World, Pettegree, Andrew (ed). London: Routledge, 2006. p. 301-305.
} 
along with an antiphonal, according to Hughes, but are often kept in separate sections of the same book. ${ }^{39}$

Below is a list of the offices with entries in the manuscript, in order of appearance:

*In many cases additional lines of chant are added to be sung at specific canonical hours or are subdivisions of a larger book. These are accounted for in the additional chants' column.

Table 6: List of Feast Days in the hymnal

\begin{tabular}{|c|c|c|}
\hline Feast Days & Heading as written in Ms. 1 & Additional Chants \\
\hline Saturday of Advent & Sabbato in adventum domini & Nones, Lauds \\
\hline Christmas & Natalis Domini & Lauds \\
\hline Epiphany & Epiphania domini & \\
\hline Saturdays of Lent & Sabbato quadragesima & Nones, Lauds \\
\hline Sundays & Dominicis diebus & \\
\hline Passion Sunday & Dominica de passione & Nones, Lauds \\
\hline First Sunday after Easter & Dominica prima post pascha & \\
\hline Eve of Ascension & Uigilia ascensio & Nones \\
\hline Eve of Holy Pentecost & Uigilia sancto pentacosta & Nones, Lauds \\
\hline Feast of the Trinity & Festo trinitatis & Nones, Lauds \\
\hline Hymn of the Body of Christ & Hymnus de corpore christi & $\begin{array}{l}\text { Nones, Lauds, Saturday at } \\
\text { Vespers, Sunday at Vespers }\end{array}$ \\
\hline $\begin{array}{l}\text { On the Conversion of Saint } \\
\text { Paul }\end{array}$ & In conuersione sancti pauli & \\
\hline $\begin{array}{l}\text { On Saint Peter's Cathedra,1 } \\
\text { at Vespers and Nones }\end{array}$ & $\begin{array}{l}\text { in cathedra sancti petri ad } \\
\text { uesperas et nona }\end{array}$ & Lauds \\
\hline
\end{tabular}

${ }^{39}$ Hughes, Andrew. Medieval Manuscripts for Mass and Office a Guide to Their Organization and Terminology. Toronto: University of Toronto Press, 1995. p.120. 


\begin{tabular}{|c|c|c|}
\hline $\begin{array}{l}\text { Hymn of Saint Antony, at } \\
\text { Vespers }\end{array}$ & $\begin{array}{l}\text { hymnus sancti antonii ad } \\
\text { uesperas }\end{array}$ & Nones, Lauds, Vespers \\
\hline Saint John the Baptist & sancti ioanne baptiste & Nones, Lauds \\
\hline Saints Peter and Paul & sanctorum petri et pauli & \\
\hline Saint Mary Magdalene & sancte mariae magdalene & \\
\hline Saint Peter in Chains & uincula sancti petri & \\
\hline $\begin{array}{l}\text { Transfiguration of Jesus, at } \\
\text { Vespers }\end{array}$ & $\begin{array}{l}\text { transfiguratio domini ad } \\
\text { uesperas }\end{array}$ & Nones, Lauds \\
\hline Saint Clare, at Vespers & sancte clare ad uesperas & Nones, Lauds, Vespers \\
\hline $\begin{array}{l}\text { Assumption of the Blessed } \\
\text { Mary }\end{array}$ & assumptione beate marie & Nones, Lauds \\
\hline Saint Louis the Confessor & sancti ludouici confessoris & Nones, Lauds, Vespers \\
\hline Hymn of Saint Michael & Hymnus sancti michaelis & Lauds \\
\hline Saint Francis & sancti francisci & Nones, Lauds, Vespers \\
\hline Feast of All Saints & festo omnium sanctorum & Lauds \\
\hline Common of the Apostles & natali apostolorum & Nones \\
\hline Common of one Martyr & de uno martire & Lauds \\
\hline Common of several Martyrs & de plurimorum martirum & Nones, Lauds \\
\hline $\begin{array}{l}\text { Hymn for the Birth of a } \\
\text { Pope }\end{array}$ & $\begin{array}{l}\text { Hymnus natum confessoris } \\
\text { pontifici }\end{array}$ & Lauds \\
\hline $\begin{array}{l}\text { Common of one Confessor } \\
\text { (not Pope), at Lauds }\end{array}$ & non pontifici ad laudes & \\
\hline Common for the Virgin & de uirginum & Nones \\
\hline Dedication of a Church & dedicatione $<$ ecclesie $>$ & $\begin{array}{l}\text { Lauds, Prime, Terce, Sext, } \\
\text { Nones }\end{array}$ \\
\hline Visitation of Mary & uisitatione beate marie & Nones \\
\hline
\end{tabular}


The selection of hymns and degrees of importance placed on them (through a variety of unique chants for canonical hours) are revealing. Importantly, key figures of the Franciscan orders are most prominent, including St. Francis himself, but also St. Clare (of the Poor Clares, second Order of St. Francis) and Saint Louis the Confessor, who is honoured as one of the most powerful and influential patrons of the Third Order of St. Francis. ${ }^{40}$ Therefore this manuscript is a liturgical chant manuscript likely copied at a Franciscan monastery. The veneration of Mary as a saint is also strong evidence of this, as Marian devotion is central to the Order as well as in Catholicism. ${ }^{41}$ There is also a lot of space allocated to the Dedication of a Church with unique chants from lauds through nones, which may have been copied for practical purposes, such as a new church being planned or constructed. The manuscript part A ends where a page has been cut between it and the beginning of part B (f.61v - 62r). This page would have belonged to part A as the transcription cuts off the text for the Visitation of Mary at nones.

\section{Manuscript part B}

Selections from the Service of Tenebrae (f.62r - 64v)

This manuscript features selections from the service of Tenebrae, which are held on the three days preceding Easter day. Manuscript part B seems to begin in an odd place, approximately halfway through first nocturnes of the Holy Thursday Service. We find the incipit for the Lamentations of Jeremiah (Lamentatio Jeremie prophete) on

\footnotetext{
${ }^{40}$ Little, Lester K. "Saint Louis' Involvement with the Friars." Church History 33, no. 2 (1964), p. 127. This patronage led to convents and friars widely flourishing throughout France during his reign (d. 1270).

${ }^{41}$ Roest, Bert. The Medieval Franciscans: Franciscan Learning, Preaching and Mission C. 1220-1650. Leiden: BRILL, 2014.p.217.; Christianson, Gerald, Bellitto, Christopher M., and Izbicki, Thomas M., eds. The Church, the Councils, and Reform : The Legacy of the Fifteenth Century. Baltimore: Catholic University of America Press, 2008. p.213
} 
f.62r. This incipit begins the first reading of Holy Thursday's first nocturne service which would typically go through Lamentations 1:1 - 1:5. However, this manuscript only provides 1:1 and 1:2 or Aleph (Hebrew, Alef $\aleph$ ) and Beth (Hebrew, Bet ב). This could be due to missing folios, as these would typically be bound together. Further evidence of this is found on f.63r as Lamentations 5:1 begins here. Lamentations 5:1 5:11 are the 3rd readings of the first nocturne on Holy Saturday of Tenebrae. Our manuscript lists these from f.63r $-64 \mathrm{v}$. There is then evidence of another cut folio, manuscript part B ends there. ${ }^{42}$ It is difficult to know why this was done, but it is known that early modern collectors disliked texts that appeared incomplete and would erase or remove pages in an effort to "neaten" the manuscripts. ${ }^{43}$ As the incipit for the Lamentations starts the page with a large rubricated drop capital, the collector may have judged this as visually "complete" but disregarded the contents of the manuscript that came before it and the intended position of the Lamentations in the service of Tenebrae. This may explain how these two unconnected manuscripts came to be one whole.

\section{Final Leaf}

Antiphon for the Immaculate Conception of Virgin Mary (f.65r - 65v)

This final page seems to have been removed from another manuscript and bound to the rest of this codex, perhaps as an attempt to reconstruct the structure of the Temporale, which features the Office of the Dead, hymnal, and the Office of the Virgin. But it is likely this leaf is distinct from both part A and B of the manuscript from codicological evidence (see palaeography: bookhand 4). The beginning and ending of the leaf are both cut off and have no match within the rest of the manuscript. Again,

\footnotetext{
${ }^{42}$ Benedictines of Solesmes (ed). The Liber Usualis: with introduction and rubrics in English, 1961. p. 626 - 762

${ }^{43}$ Clemens, Raymond, and Timothy Graham. Introduction to Manuscript Studies. Ithaca:

Cornell University, 2007. p.111-112.
} 
this may be an example of early modern alteration (or the strategic removal of leaves) to make the text appear more complete. There is also the possibility that this leaf may be an early modern imitation of the original bookhand, but there is currently not enough evidence to support this theory. ${ }^{44}$

\subsection{Corrections and Annotations}

The Carleton Antiphonary has a rich variety of corrections and annotations, some contemporary and others more modern. The contemporary annotations are chiefly corrections and guidewords, but make up the majority of the annotations found in the book. Another kind of contemporary annotation can be found in the manuscript, however. On f.30v (during the Office of the Dead) a three-line stave and alternate musical notation for the Kyrie was added to the bottom margin of the folio. This music is more malismatic than the simplified version on the page above it which could indicate it was for use during special occasions (a notable death, for example) or by more practiced students.

Interestingly, on $\mathrm{f} .37 \mathrm{r}$ there is an early modern annotation of a four-lined stave and musical notation also concerned with the Kyrie, in the bottom margin of the folio. This annotation is an extension of the chant rather than a variation. We see this practice of extending the notation in the top exterior margin of the same folio, where they seem to be clarifying the close-together and difficult to read notation found on the line below (figure 18).

\footnotetext{
${ }^{44}$ Clemens, Raymond, and Timothy Graham. Introduction to Manuscript Studies. Ithaca: Cornell University, 2007. p.111-112.
} 

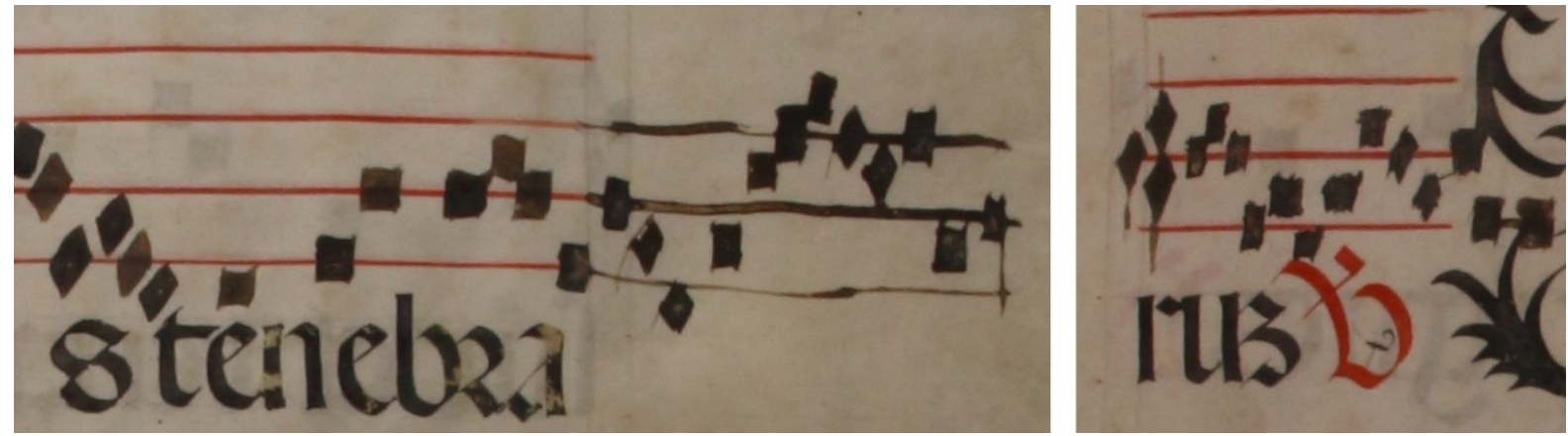

(figure 20: f. 37r. Left: Added musical notes by early modern hand Right: original notation in primary bookhand)

The contemporary hand has added another musical notation to the exterior margin of f.28r, but this time there has been no attempt to make it blend in with the rest of the book. It is written on its side, features a single line stave and writes out the verse "Audivi vocem de caelo dicentem mihi". ${ }^{45}$ This was meant to be added before the Antiphon Ad Magnificat but the rubricated X for Versus was never inked. Therefore, it had to have been added later in the margins (Figure 19).

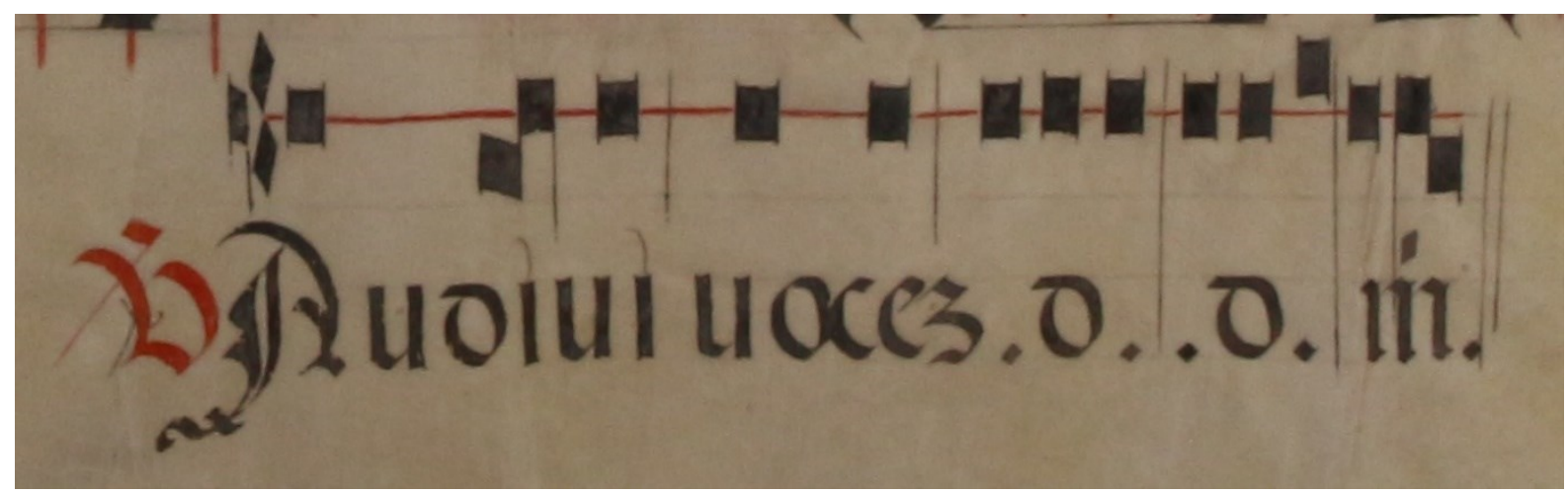

(Figure 21:f.28r "Audivi vocem de caelo dicentem mihi" written in margins to correct mistake)

${ }^{45}$ Cantus ID: 007957 
Beginning on folio $27 \mathrm{r}$, a modern hand has written in expansions above abbreviated words in pencil (Figure 20). At times incorrect, such as the correction "animas tuas" given for "animam tua3" on f.27v. It appears the annotator intended to correct the Office of Dead, as the ammendations begin immediately after the Incipit for the Office. However, only three pages were ultimately marked, ending on f.28r.

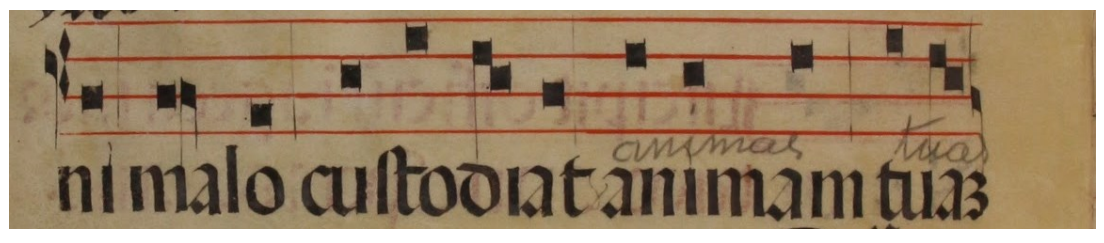

(Figure 22: $f .27 v$ with pencil annotations reading “animas tuas”)

For a more complete study of the compound manuscript's fragments, including their contents, please see Chapter 1.5 of this work.

\subsection{Conclusions}

This study of the manuscript's contents provides information about the book as an artefact, detailing its origins and history over the past 500 years. We understand that the first manuscript (part A) that makes up the whole of this compound manuscript was created as a teaching tool as well as a devotional book as it opens with a tonary. Tonaries would have been added to instruct monks on the eight modes of Gregorian chant. Furthermore, the Office of the Dead and hymnal provide us with insight into its creators. We know that it was created by a Franciscan order as prominent hymns are dedicated to notable figures of the order such as St. Francis, St. Clare, and Saint Louis the Confessor. 
Sometime after the manuscript left monastic hands, a Spanish owner possessed it which is evident through the quick humanist script they wrote with, and the replacement of Vs for Bs (sounds that become indistinguishable in Spanish) in the Credo which they copied into the blank staves of the manuscript.

The second manuscript (part B) that makes up the compound manuscript is the result of early modern collections appending pages to the manuscripts to make them appear more complete. Therefore the first page features the Incipit for the Lamentations of Jeremiah despite these readings appearing well into the service of Tenebrae. The final leaf, distinct from the rest of the manuscript, again reveals the workings of early modern collectors who attempted to make the book appear more complete or 'neat' as the final page may have been considerably damaged.

The presence of annotations throughout the manuscript, both contemporary and modern, demonstrate the care and continuous use of this manuscript throughout its life. The contemporary annotations illustrate the special and ongoing care received by the book by its monastic creators. The early modern additions, particularly the Credo on f.42r - 43r, indicate the manuscript left monastic hands and was held by a wealthy, likely secular (based on the cursiva script), individual. It was then acquired by early modern collectors who altered the manuscript. Modern annotations reveal the book was used anew as a studying and devotional tool, as the annotator attempted to expand the Latin abbreviations of the original bookhand.

This examination of the manuscript's contents gives evidence of the continuous life of this medieval book for over 500 years since its creation. Its purpose as an artefact changed as its owners changed, and was at once a devotional object, teaching tool, and medieval artefact throughout its rich history. I hope this effort will contribute to its 
further study and care as access to its history and contents, including its structure and distinct parts become more available through this digital project. 


\section{Chapter 3: The Digital Edition}

3.1 How to read this edition

This transcription of the manuscript's text is a visual reproduction, and a diplomatic edition. A diplomatic edition is an edition that attempts to reproduce the original spelling, punctuation, scribal mistakes (including corrections and deletions) and abbreviations. In this digital edition, I have placed the images of each manuscript page on the left hand side. On the right side, I offer a transcription which does not regularize or modernize the Latin, but rather retains scribal mistakes, abbreviated characters, and punctuation as it exists in the manuscript. Given the unique nature of liturgical manuscripts, I did not seek to establish a comparative critical edition-i.e. the product of studying multiple manuscripts to construct a final version with the cumulative information from each codex. Rather, my edition, as it lives in the digital realm, seeks to let the user guide their interaction with the text. They can consult the original manuscript (in digitized images), they can consult a direct transcription of the text alongside the images, they can also read the alternate text with abbreviations unpacked and punctuation regularized. Given the potential for non-linear usage, I consider my edition a hypertext edition, because the linked presentation of information achieves through the digital format something unlike traditional print texts. ${ }^{46}$

\section{Privileging transcription over finished edition}

The benefit of a transcription over a finished edition is that researchers can easily follow the palaeographical and codicological aspects of this manuscript through the non-linear use I have described above. This decision was made because Carleton

\footnotetext{
46 "Types of Editions" Harvard's Geoffrey Chaucer Website (2020, Harvard University). Accessed March 26, 2020. https://chaucer.fas.harvard.edu/types-editions\#criticaledition.
} 
Antiphonary, like most liturgical manuscripts, is unique in its physical composition not only by the nature of handmade work but also because so many liturgical manuscripts were distinct products of their time, location, and monastic tradition. The decision to make the transcription and edition digital was in large part a question of access, especially because Carleton University, as a Canadian institution, must rely heavily on digital content for the study of European manuscripts.

\section{Digital Format}

Because of the digital format, the text can be shown in numerous ways without compromising user experience, i.e. the reader does not need to constantly refer to the index and appendices at the back of a paper copy to make sense of the text. As you will see, in order to unpack an abbreviation or symbol as presented in the manuscript in the transcription, the user must simply hover over the word or symbol to have it unpacked (with the exception of common usage symbols, as listed in table 7, below).

\section{Abbreviations}

The table below outlines the abbreviations used throughout the Carleton Antiphonary and explains which Unicode symbols were used to mimic the manuscript's forms. The expansion or modern equivalent are also given, with multiple possible expansions where applicable. The rightmost column displays whether the abbreviations have been unpacked in the hypertext edition. Note that symbols that replace single letterforms (e.g. २, d, and 3) are not unpacked in this transcription but abbreviations with two or more letters are unpacked to maintain clarity for the researcher while using this tool. 
Table 7: Abbreviations for the hypertext edition of the Carleton Antiphonary

\begin{tabular}{|c|c|c|c|}
\hline Symbol & Type & Expansion or modern equivalent & Unpacked? \\
\hline 2 & Latin Rotunda $r$ & $\mathrm{r}$ & No \\
\hline d & Latin uncial d & $d$ & No \\
\hline $\mathrm{X}$ & $\begin{array}{l}\text { Latin capital V with } \\
\text { stroke }\end{array}$ & Versus/ Versum & Yes \\
\hline 9 & Latin abbreviation for con & - con & Yes \\
\hline 3 & $\begin{array}{l}\text { Rotunda } \mathrm{m} \text {, oriented } \\
\text { vertically }\end{array}$ & $-\mathrm{m}$ & No \\
\hline $\mathrm{p}$ & Latin abbreviation for pre & pre / per & Yes \\
\hline $\mathrm{q} 3$ & Latin abbreviation que & -que & Yes \\
\hline $\mathrm{p}$ & Rotunda pr & pr- / pro- & Yes \\
\hline r & Long $\mathrm{s}$ & s & No \\
\hline $1^{+}$ & Latin abbreviation rum & -rum & Yes \\
\hline Ј & Latin inverted c & con- & Yes \\
\hline q & Latin que & que & Yes \\
\hline $\mathrm{xp}$ & Chi rho & Chr- & Yes \\
\hline 7 & Tironian 'et' & et & Yes \\
\hline
\end{tabular}

Image files

The images found on the website were originally produced in TIFF, which were far too large (approximately 5 - $6 \mathrm{Mi}$ each) even for modern web standards. From a web-friendly point of view, the images had to be cropped and resized to allow for quick load times on the website. Although the TIFF files would have provided extremely clear images for the scrutiny of minute details of the manuscript that in-depth manuscript study often demands, this decision came from a user experience (UX) stand-point to ensure compatibility with the widest range of browsers. That being said, the images are 
still high-quality $(362 \mathrm{~KB}, 685 \times$ x 923) and useful for study. Furthermore, they are available for download so scholars may quickly and frequently access them.

These images were taken with a digital camera, (Canon EOS REBEL T5i) with less than ideal lighting, but in future we hope to produce scans of the manuscript. Unfortunately, we did not have access to a large enough scanner at the time of this project. This presented unique challenges because the orientation, lighting, and dimensions of each image were distinct. In other words, each of the 148 original images would have to be manually manipulated. Therefore, the batch image processor IrfanView, a freeware (proprietary but free to use) software for Windows users, was used to resize the images to a standard size. This allowed the website to display the folios in a streamline and consistent fashion, giving the reader a book-like experience despite the vastly different sizes and orientation of the original images. As you will see, the result is not perfect, but provides a far more attractive product in the final version.

\subsection{Web Edition vs Paper Version}

When I was first introduced to the Carleton Antiphonary in 2016 Carleton University's Archives and Research Collections had not yet digitally catalogued any of their medieval materials, nor do they exist in the library's catalogue. For researchers, it was as if the manuscript did not exist. This project sought to address this problem by creating an online edition for the codex, circumventing the issues with access intrinsic to the printed edition. The main issue that was apparent to me was access to the edition. It could be written in printed or PDF format and lay hidden in a university's catalogue, where researchers from both Carleton and elsewhere may never know of its existence, closing the initial circle that I sought to address. But a digital project, connected to a 
popular public database such as the Cantus Database, would have more visibility and would contribute to the mission of bringing this manuscript to light. ${ }^{47}$

\section{Broader Access}

Some of these fundamental issues are that the commentary and glossary are usually separate from the transcription, segregated to the end of the paperback, often rendering it cumbersome for reference. Furthermore, a printed work must be produced, published, and distributed before it is accessible to scholars. Electronic editions, however, change this process - making editions not a product but a process that can be published online while in progress to allow other scholars to make use of the work and possibly to contribute to it. In essence, once the work is online and accessible (usually through an institution) it is catalogued and therefore referenceable, unlike projects which are left to languish gathering dust within the shelves upon shelves of uncatalogued theses.

Scholars of medieval liturgy and codicology can know of the manuscript's existence and perhaps reveal some of its long-held secrets through this diplomatic edition. Important to note is that the website was purpose built in collaborating with Ryan Lacroix (Developer) in order to showcase this manuscript in ways suited to its study as both an object and a document.

\section{Cantus Index}

Cantus is a manuscript database used to reference medieval and early modern Latin ecclesiastical sources. The resource was created by the University of Waterloo and is managed collaboratively by Debra Lacoste (University of Waterloo) and Jan

\footnotetext{
${ }^{47}$ http://cantus.uwaterloo.ca/
} 
Koláček (Charles University, Prague). It has nine major databases connected to it from across the globe and over 150 sources. Each source is indexed according to its chants and connected with any concordant chants from other sources. Each chant has a unique Cantus ID number that is used to reference the list of chants in the Cantus Index, a catalogue for the Cantus Database. In the Manuscript Reading (Ms spelling) transcription I have identified each segment of the manuscript by the appropriate Cantus ID (see Appendices). ${ }^{48}$ This allows researchers to quickly analyse the various parts of the manuscript and find contextual data for that particular segment. Cantus provides details such as associated feast days, genre, position in office or mass, and a list of the concordances for each chant. Users may further research by perusing the hundreds of manuscript holdings digitally uploaded by institutions onto Cantus Database through the identifiers. Interconnectivity with scholarly platforms such as Cantus which have already made waves in the digital realm is fundamental to this project. It allows the website to be both accessible as a website and flexible as a tool to meet the growing demands of modern scholarship.

\section{Open Source}

This project embraces the idea of collaboration and transparency in the digital realm and builds upon the developments of digital academics in the field of manuscript studies. That is why all stages of this project were accomplished using largely open source and free to use software. Furthermore, all the code purpose written for this project is available to others to use and modify for their own future projects via Github.

\footnotetext{
48 Unless indicated as unidentified.
} 


\subsection{Stages of Production}

In order to illustrate the process of creating a born-digital manuscript edition, I provided below a roadmap for my project. I discuss the methods and guidelines I consulted, and I reflect on the limitations and advantages of the various software and platforms I used. I also highlight here where the contributions were a collaborative effort with Lacroix. For more information on editorial decisions I made please see how to read this edition.

\section{Using Transkribus}

Before I could begin to pull my research into a cohesive place, I needed a workable transcription of the manuscript. In order to create a digital transcription of the manuscript, I needed a robust tool that could serve over 130 high quality images and would preferably be an open access (free to use) tool. Developers at the University of Innsbruck, Austria, had developed a tool, Transkribus, that met nearly all my specifications. This tool automatically recognizes historical written and printed text and builds an intuitive structure around textual elements to make transcription easier. Importantly, it hosts users' images to the Transkribus server to create "private collections" that limit access to the original user and those they chose to share their collection with. Moreover, the tool allows scholars to write in any language using any character set (this project required the extended Latin Unicode alphabet). A limitation of Transkribus is the intensive core text necessary before the computer-driven handwriting analysis is viable. There was insufficient text in the manuscript to allow me to use this feature. 
Working with XML files

The major caveat of using the Transkribus software was its output format. Transkribus outputs thousands of lines of XML code containing a proprietary string format that represents the coordinates of each identified element of text (including rubrication, position of lines of text, drop capitals, etc.). The string format does not follow XML standards and therefore required a custom parser that detected the location information of the various tags (indicating the important textual elements of the document) for it to be correctly displayed on the website. However, this transcription when converted to HTML gave many errors and would have required manually editing hundreds of lines of code to debug. So, Lacroix and I turned to the TEI output as a possible solution.

Working the TEI

Transkribus exports in several formats, including TEI (Text Encoding Initiative), PDF, and XML (Extensible Markup Language). TEI guidelines, the ideal for many digital humanists, define and shape the XML format to be compatible between digital humanities projects. ${ }^{49}$ The payload of this initiative is a vigorous tagging system that documents and describes structural and textual elements of virtually any type of document. Because the TEI has a large body of documentation on its robust tagging system, another custom parser was written by Lacroix to convert the code to HTML in the hope that I would not have to manually debug the code. This method indeed proved better than the first, and the parser successfully produced a workable HTML version of the transcription for use on the website.

49 “TEI: Guidelines", TEI: Text Encoding Initiative. (October 2007, TEI Consortium). https://teic.org/guidelines/ 
Creating the Website

In the early stages of this project, I conceptualized the website as being made with a web builder (e.i. Wordpress, Wix) to save time and labour. However, several issues arose with these platforms that were irreconcilable with my vision for the site. Chiefly, it was key that the website have an interactive transcription portion. The exact functionality of it does not come out of the box in any website builders. Therefore, the website had to be custom built. I wanted to be able to display the transcription and facsimiles side by side in a way that the user can interact with the manuscript in a variety of ways. Website builders do not offer this functionality, nor are you able to embed code necessary for it into a website builder in both unpaid and paid options. The issue is that website builders do not give the user access to its backend, and the interactive transcription demands that large amounts of images be hosted on a server connected to the site. Furthermore, website builders come with a lot of extra functionality and "bulk" that can be cumbersome. In the end, having full control of the website was the best way to ensure the result I intended.

The website was created from scratch by Lacroix and myself using node.js and a vanilla JavaScript, HTML, CSS front end. Styling for the website itself was handled with Bootstrap4. This provided a baseline in which to build the custom styling for the website. To properly illustrate the structure and contents (rubrication, hierarchy of structure) of the manuscript transcription, corresponding HTML attributes were added to the transcriptions to style the various tags (e.i. rubrication, drop-capitals, and so on) with CSS. The hover-over feature that expands abbreviations was done using JavaScript. The modal that appears when users access the interactive transcription that displays basic usage instructions was added with Bootstrap4. 


\section{Heroku}

Heroku is a cloud application platform that allows users to manage their servers for free. The website had to be hosted and Heroku provides a server that hosts the site, the images, and the transcriptions. The limitations of using the free Heroku service are that the server goes to sleep after thirty minutes of inactivity (an approximate $5 \mathrm{sec}$ delay upon loading) and there is a limit of 1000 hours available per month. However, since only one app is running, this makes no difference as the website can be run continuously. Heroku is also well documented and has a large community for support resources that can help newcomers to the tool and developers to use the platform and troubleshoot problems as they arise.

\section{Licensing}

I chose to license the website and tool under the Attribution-NonCommercial CC BY-ND license so that the website may be used and built upon by anyone if the usage is non-commercial. I chose this because the guiding principle of this project and tool has been to be openly accessible to all users. This license also permits derivatives of this work to be licensed on different terms if the modifier so chooses.

\subsection{Conclusions}

Digital projects are more of a process than a final product, and as such are constantly evolving. What I have done provides the foundations for further research and further questions. Chief among these are, where to go from here?

Ideally, the next steps for this project would be to: 
- Crowdsource the musical notation for this codex. Having no musical experience, I made the decision not to attempt a transcription of the musical notation found in this chant manuscript. A logical next step for this project would therefore be a transcription of the manuscript's plainchant notation and subsequent integration into the Cantus database.

- Integrate manuscript (including musical notation) into the Cantus database.

\section{Conclusion}

Medieval manuscripts, as unique objects that cannot ever be truly replicated, have posed a significant challenge in our globalized world. Access to manuscripts is vital for researchers but the question of how best to bring them into the digital world for easy access (while still maintaining its character as a distinct physical object) had to be asked. This project has sought out to answer this question with a particular take on digital recreation. There are many ways to digitally present a manuscript, this is only one of many. Importantly, I wanted to keep in mind that these objects are both documents and visual art. Therefore, special emphasis was placed on images and an analysis of what is shown on a manuscript leaf or leaves. Indeed, the palaeography and scribal nuances proved to be invaluable in deciphering the origin of the Carleton Antiphonary.

Codicological evidence and content analysis revealed much about the manuscript's use and relationship to its owners throughout time. This information is made available in peripheral pages surrounding the interactive transcription on the website. This tool juxtaposes images and transcription to offer users a way to engage with this manuscript digitally in a way that at once attempts to recreate the text as it was 
originally copied and brings in contextual knowledge to further our understanding of the codex. Furthermore, the roadmap to the project which makes up the second part of this endeavour is advantageous for users who are seeking to establish their own digital copies. In fact, it has been my intention from the start to demonstrate that projects such as this have a role to play in bringing medieval materials out of the proverbial dark and allowing them once again to be catalogued and studied by users around the globe. 
Plates (Comparative manuscripts)

Spanish Rotunda circa 1500-1600.

\begin{tabular}{|c|c|c|c|}
\hline Call No. & Plate no. & Info. & Link (Images) \\
\hline MPCANT/1 & 1 & $\begin{array}{l}\text { Biblioteca Digital } \\
\text { Hispanica, Catholic chant } \\
\text { manuscript, Spain, } 1501 .\end{array}$ & $\begin{array}{l}\text { http://bdh- } \\
\text { rd.bne.es/viewer.vm?id=000016 } \\
\text { 8313\&page=1 }\end{array}$ \\
\hline MPCANT/9 & 2 & $\begin{array}{l}\text { Biblioteca Digital } \\
\text { Hispanica, Catholic chant } \\
\text { manuscript (antiphonary), } \\
\text { Spain, } 1501 .\end{array}$ & $\begin{array}{l}\text { http://bdh- } \\
\text { rd.bne.es/viewer.vm?id=000016 } \\
\text { 8323\&page }=1\end{array}$ \\
\hline $\begin{array}{l}\text { MPCANT/3 } \\
1\end{array}$ & 3 & $\begin{array}{l}\text { Biblioteca Digital } \\
\text { Hispanica, Catholic chant } \\
\text { manuscript (antiphonary), } \\
\text { Spain, } \\
1501 .\end{array}$ & $\begin{array}{l}\text { http://bdh- } \\
\text { rd.bne.es/viewer.vm?id=000016 } \\
\text { 8388\&page=1 }\end{array}$ \\
\hline $\mathrm{M} / 2205(1)$ & 4 & $\begin{array}{l}\text { Biblioteca Digital } \\
\text { Hispanica, Catholic chant } \\
\text { manuscript, Spain, } 1501 \text { - } \\
1600 .\end{array}$ & $\begin{array}{l}\text { http://bdh- } \\
\text { rd.bne.es/viewer.vm?id=000000 } \\
\text { 4929\&page=45 }\end{array}$ \\
\hline $\begin{array}{l}\text { Cantus, } \\
\text { AUS-Sfl } \\
\text { Add. Ms. } \\
413 . \\
\text {------------ } \\
\text { University } \\
\text { of Sydney, } \\
\text { Rare Books } \\
\text { and Special } \\
\text { Collections, } \\
\text { Add.Ms.413 }\end{array}$ & 5 & $\begin{array}{l}\text { Digital Library of the } \\
\text { University of Sydney, } \\
\text { Franciscan Antiphonary, } \\
\text { Spain, } 1550 \text { - } 1600 .\end{array}$ & $\begin{array}{l}\text { https://digital.library.sydney.edu. } \\
\text { au/nodes/view/6380\#idx52792 }\end{array}$ \\
\hline
\end{tabular}




\section{Bibliography}

Print and Electronic Resources

Benedictines of Solesmes (ed). The Liber Usualis: with introduction and rubrics in English. New York: Desclee co., 1961.

Capelli, Roberta. "Practical and Theoretical Implications of Digitizing the Middle Ages" CLCWeb: Comparative Literature and Culture 15.3 (2013):

$<$ https://doi.org/10.7771/1481-4374.2248>

Chambers, John David. The Psalter, or Seven Ordinary Hours of Prayers, London: J. Masters and Co. 1852.

Clemens, Raymond, and Timothy Graham. Introduction to Manuscript Studies. Ithaca: Cornell University, 2007.

Clementis VIII, and Urbani VIII, Missale Romanum, 1817.

Davis, Matthew Evan, Turnator, Ece, and Mahoney-Steel, Tamsyn, eds. Meeting the Medieval in a Digital World. Amsterdam: Arc Humanities Press, 2018. $<$ https://ebookcentral-proquest-com.proxy.library.carleton.ca/lib/oculcarletonebooks/reader.action?docID $=5718288 \& p p g=239>$

de Bonald, Louis Jacques Maurice Cardinal de Lyon. Eucologe dédié à Marie, ou Heures Nouvelles du Diocèse de Lyon, contenant Les Offices Complets, accompagnés du plain-chant. La Guillotière: J.M. Bajat Père, Fils et c., 1851.

Derolez, Albert. The Palaeography of Gothic Manuscript Books: from the Twelfth of the Early Sixteenth Century. Cambridge: Cambridge University Press, 2012.

Driscoll, Matthew James (ed.); Pierazzo, Elena (ed.). Digital Scholarly Editing: Theories and Practices. New edition [online]. Cambridge: Open Book Publishers, 2016.<http://books.openedition.org/obp/3381>. ISBN: 9782821884007.

Eucologe Romain: A L'Usage Des Collèges, 17th edition. Librairie de Poussielgue Frères, 1885.

Fagin Davis, Lisa. "The Promise of Digital Fragmentology" Manuscript Road Trip. (Blog) July 13, 2015. $<$ https://manuscriptroadtrip.wordpress.com/2015/07/13/manuscript-road-tripthe-promise-of-digital-fragmentology/> 
Gwara, Scott. Otto Eges Manuscripts: a Study of Eges Manuscript Collections, Portfolios, and Retail Trade, with a Comprehensive Handlist of Manuscripts Collected or Sold. Cayce, SC: De Brailes, 2013.

Hiley, David. Western Plainchant: A Handbook. Oxford: Clarendon Press, 1993.

Hughes, Andrew. Medieval Manuscripts for Mass and Office a Guide to Their Organization and Terminology. Toronto: University of Toronto Press, 1995.

Knight, Stan "Section 24: The Roman Alphabet" in The World's Writing Systems. Daniel, Petter T. and Bright, Williams (eds.) New York: Oxford University Press, 1996.

Kwakkel, Erik. "Breaking Bad: The Incomplete History of the St Albans Bible" MedievalBooks. (Blog) November 1, 2019.

$<$ https://medievalbooks.nl/2019/11/01/breaking-bad/ $>$.

Ledgeway, Adam, and Martin Maiden. The Oxford Guide to the Romance Languages. Oxford: Oxford University Press, 2016. p.388

Little, Lester K. "Saint Louis' Involvement with the Friars." Church History 33, no. 2 (1964): 125-48. Accessed April 10, 2020. www.jstor.org/stable/3162976.

Missale Romanum, ex decreto sacrosancti Concilii Tridentini restitutum. Pii V. Pont. Max. Jussu editum. Paris: Societatem Typographicam Librorum Officii Ecclesiastici, 1817.

Pettegree, Andrew. Reformation World. London: Taylor \& Francis Group, 2000.

Simpson, Elizabeth (ed.). Spoils of War - World War II and Its Aftermath: The Loss, Reappearance, and Recovery of Cultural Property, New York: Harry N. Abrams, inc., 1997.

Wieck, Roger S. "Folia Fugitiva: The Pursuit of the Illuminated Manuscript Leaf, The Journal of the Walters Art Gallery, Vol. 54, The Walters Art Museum (1996), pp. 233-254. <https://www.jstor.org/stable/20169120> 
Web Resources

- Digital Humanities Resources

"Types of Editions" Harvard's Geoffrey Chaucer Website (2020, Harvard University). Accessed March 26, 2020. https://chaucer.fas.harvard.edu/typeseditions\#criticaledition.

Dunning, Andrew. "Transcribing medieval manuscripts with TEI". (January 28, 2019). Accessed July 2019. https://andrewdunning.ca/transcribing-medievalmanuscripts-tei.

“TEI: Guidelines”, TEI: Text Encoding Initiative. (October 2007, TEI Consortium). Accessed March 2020. https://tei-c.org/guidelines/.

- Codicological and Liturgical Resources

The Arnamagnæan Institute, Manuscript.ku.dk. (2020, University of Copenhagen). Accessed April 9th, 2020. https://manuscript.ku.dk/manuscript_types/liturgical/.

British Library, "Glossary for the British Library", Catalogue of Illuminated Manuscripts. https://www.bl.uk/catalogues/illuminatedmanuscripts/glossary.asp

Boardley, John. 2016. "The First Roman Fonts." I Love Typography, accessed on April 20, 2020. http://ilovetypography.com/2016/04/18/the-first-roman-fonts/

Martin, Michael. 2016. "Symbolum Nicaenum”, Treasury of Latin Prayers, accessed on April 20, 2020. http://www.preces-latinae.org/thesaurus/Symbola/Nicaenum.html 


\section{Appendix}

\section{Accessing the Website}

To access the website, copy and paste this URL (https://carleton-

antiphonary.herokuapp.com/index.html) into your preferred browser. Please allow up to 10 seconds for the website to initially load. 


\section{Manuscript transcription with Cantus IDs}

Sequitur inuitatorium $:^{50}$

primi toni

Uenite exultemus domino iubilemus deo salutari nostro preoc $<\mathrm{c}>$ upemus faciem eius in confessione et in psalmis iubilemus ei.

Uersus Quoniam deus magnus dominus [f.1v] et rex magnus super omnes deos. Quoniam non repellet dominus plebem suam quia in manu eius sunt omnes fines terre et altitudines moncium ipse conspicit.

Uersus Quoniam ipsius est mare [f.2r] et ipse fecit illud et aridam fundauerunt manus eius. Uenite adoremus et procidamus ante deum ploremus coram domino qui fecit nos quia ipse est dominus deus noster nos autem populus $[\mathrm{f} .2 \mathrm{v}]$ eius et oues paschue eius.

Uersus Hodie si uocem eius audieritis nolite obdurare corda uestra. Sicut in exacerbatione secundum diem temptationis in deserto ubi tentauerunt me $\mathrm{pa}[\mathrm{f} .3 \mathrm{r}]$ tres uestri probauerunt et uiderunt opera mea

Uersus Quadraginta annis proximus fui generationi huic et dixi semper hii errant corde. Ipsi uero non cognouerunt uias meas quibus iuraui $[3 \mathrm{v}]$ in ira mea si introibunt in requiem meam

Uersus Gloria patri et filio et spiritui sancto. Sicut erat in principio et nunc et semper et in secula seculorum. Amen.

\section{Secundus tonus}

Uenite exultemus domino [f.4r] iubilemus deo salutari nostro preoc $<c>$ upemus faciem eius in confessione et in psalmis iubilemus ei.

Uersus Quoniam deus magnus dominus et rex magnus super omnes deos. Quoniam non repellet dominus [f.4v] plebem suam quia in manu eius sunt omnes fines terre et altitudines moncium ipse conspicit.

Uersus Quoniam ipsius est mare et ipse fecit illud et aridam fundauerunt manus eius. Uenite adore[f.5r]mus et procidamus ante deum ploremus coram

${ }^{50}$ Cantus ID: 909030 
domino qui fecit nos quia ipse est dominus deus noster nos autem populus eius et oues paschue eius.

Uersus Hodie si uocem eius audie[f.5v]ritis nolite obdurare corda uestra. Sicut in exacerbatione secundum diem temptationis in deserto ubi tentauerunt me patres uestri probauerunt et uiderunt opera mea

Uersus Quadraginta [f.6r]annis proximus fui generationi huic et dixi semper hii errant corde. Ipsi uero non cognouerunt uias meas quibus iuraui in ira mea si introibunt in requiem meam

Uersus Gloria patri et filio [f.6v] et spiritui sancto.

Uersus Sicut erat in principio et nunc et semper et in secular seculorum. Amen.

\section{Tertius tonus}

Uenite exultemus domino iubilemus deo salutari nostro preoc $<\mathrm{c}>$ upemus faciem eius [f.7r] in confessione et in psalmis iubilemus ei.

Uersus Quoniam deus magnus dominus et rex magnus super omnes deos. Quoniam non repellet dominus plebem suam quia in manu eius sunt omnes fines $[\mathrm{f} .7 \mathrm{v}]$ terre et altitudines moncium ipse conspicit.

Uersus Quoniam ipsius est mare et ipse fecit illud et aridam fundauerunt manus eius. Uenite adoremus et procidamus ante deum ploremus coram [f.8r] domino qui fecit nos quia ipse est dominus deus noster nos autem populus eius et oues paschue eius.

Uersus Hodie si uocem eius audieritis nolite obdurare corda uestra. Sicut in exacer[f.8v]batione secundum diem temptationis in deserto ubi tentauerunt me patres uestri probauerunt et uiderunt opera mea

Uersus $Q$ uadraginta annis proximus fui generationi huic [f.9r] et dixi semper hii errant corde. Ipsi uero non cognouerunt uias meas quibus iuraui in ira mea si introibunt in requiem meam

Uersus Gloria patri et filio et spiritui sancto. Sicut [f.9v] erat in principio et nunc et semper et in secular seculorum. Amen. 
Uenite exultemus domino iubilemus deo salutari nostro preoc $<\mathrm{c}>$ upemus faciem eius in confessione et in psalmis iu[f.10r]bilemus ei.

Uersus $\mathbf{Q}$ uoniam deus magnus dominus et rex magnus super omnes deos. Quoniam non repellet dominus plebem suam quia in manu eius sunt omnes fines ter[f.10v]re et altitudines moncium ipse conspicit.

Uersus Quoniam ipsius est mare et ipse fecit illud et aridam fundauerunt manus eius. Uenite adoremus et procidamus ante deum plo[f.11r]remus coram domino qui fecit nos quia ipse est dominus deus noster nos autem populus eius et oues paschue eius.

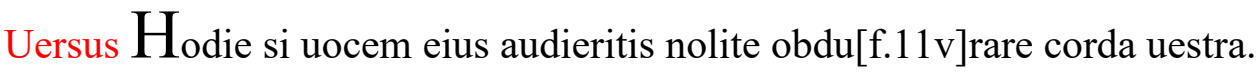
Sicut in exacerbatione secundum diem temptationis in deserto ubi tentauerunt me patres uestri probauerunt et uiderunt opera mea

Uersus $Q$ uadraginta annis proxi[f.12r]mus fui generationi huic et dixi semper hii errant corde. Ipsi uero non cognouerunt uias meas quibus iuraui in ira mea si introibunt in requiem meam

Uersus Gloria [f.12v] patri et filio et spiritui sancto. Sicut erat in principio et nunc et semper et in secular seculorum. Amen.

\section{Alius quartus tonus}

Uenite exultemus domino iubilemus deo salutari nostro preoc $<\mathrm{c}>$ upemus [f.13r] faciem eius in confessione et in psalmis iubilemus ei.

Uersus Quoniam deus magnus dominus et rex magnus super omnes deos. Quoniam non repellet dominus plebem suam [f.13v] quia in manu eius sunt omnes fines terre et altitudines moncium ipse conspicit.

Uersus Quoniam ipsius est mare et ipse fecit illud et aridam fundauerunt manus eius. Uenite ado[f.14r]remus et procidamus ante deum ploremus coram domino qui fecit nos quia ipse est dominus deus noster nos autem populus eius et oues paschue eius. 
Uersus Hodie si uocem eius audi[f.14v]eritis nolite obdurare corda uestra. Sicut in exacerbatione secundum diem temptationis in deserto ubi tentauerunt me patres uestri probauerunt et uiderunt opera mea

Uersus Quadraginta [f.15r] annis proximus fui generationi huic et dixi semper hii errant corde. Ipsi uero non cognouerunt uias meas quibus iuraui in ira mea si introibunt in requiem meam

Uersus Gloria patri et fi[f.15v]lio et spiritui sancto. Sicut erat in principio et nunc et semper et in secular seculorum. Amen.

Tonus quintus

Uenite exultemus domino iubilemus deo salutari nostro preoc $<\mathrm{c}>$ upemus faciem [f.16r] eius in confessione et in psalmis iubilemus ei.

Uersus Quoniam deus magnus dominus et rex magnus super omnes deos. Quoniam non repellet dominus plebem suam [f.16v] quia in manu eius sunt omnes fines terre et altitudines moncium ipse conspicit.

Uersus Quoniam ipsius est mare et ipse fecit illud et aridam fundauerunt manus eius. [17r] Uenite adoremus et procidamus ante deum ploremus coram domino qui fecit nos quia ipse est dominus deus noster nos autem populus eius et oues pascue eius.

Uersus [f.17v] Hodie si uocem eius audieritis nolite obdurare corda uestra. Sicut in exacerbatione secundum diem temptationis in deserto ubi tentauerunt me patres uestri proba[f.18r]uerunt et uiderunt opera mea

Uersus Quadraginta annis proximus fui generationi huic et dixi semper hii errant corde. Ipsi uero non cognouerunt uias meas quibus [f.18v] iuraui in ira mea si introibunt in requiem meam

Uersus Gloria patri et filio et spiritui sancto. Sicut erat in principio et nunc et semper et in secular seculorum. Amen. [f.19r]

\section{Sextus tonus}

Uenite exultemus domino iubilemus deo salutari nostro preoc $<\mathrm{c}>$ upemus faciem eius in confessione et in psalmis iubilemus ei. 
Uersus Quoniam deus magnus [f.19v] dominus et rex magnus super omnes deos. Quoniam non repellet dominus plebem suam quia in manu eius sunt omnes fines terre et altitudines moncium ipse conspicit.

Uersus Quoniam ipsius est mare [f.20r] et ipse fecit illud et aridam fundauerunt manus eius. Uenite adoremus et procidamus ante deum ploremus coram domino qui fecit nos quia ipse est dominus deus noster nos autem $[f .20 \mathrm{v}]$ populus eius et oues paschue eius.

Uersus Hodie si uocem eius audieritis nolite obdurare corda uestra. Sicut in exacerbatione secundum diem temptationis in deserto ubi tempta[f.21r]uerunt me patres uestri probauerunt et uiderunt opera mea

Uersus Quadraginta annis proximus fui generationi huic et dixi semper hii errant corde. Ipsi uero non cognouerunt uias meas quibus iuraui [f.21v] in ira mea si introibunt in requiem meam

Uersus Gloria patri et filio et spiritui sancto. Sicut erat in principio et nunc et semper et in secular seculorum. Amen.

\section{Septimus tonus}

Uenite exultemus domino [f.22r] iubilemus deo salutari nostro preoc $<\mathrm{c}>$ upemus faciem eius in confessione et in psalmis iubilemus ei.

Uersus Quoniam deus magnus dominus et rex magnus super omnes deos. Quoniam non repellet [f.22v] dominus plebem suam quia in manu eius sunt omnes fines terre et altitudines moncium ipse conspicit.

Uersus Quoniam ipsius est mare et ipse fecit illud et aridam fundauerunt manus eius. Uenite adoremus et [f.23r] procidamus ante deum ploremus coram domino qui fecit nos quia ipse est dominus deus noster nos autem populus eius et oues paschue eius.

Uersus Hodie si uocem eius audieritis nolite obdurare corda ues[f.23v]tra. Sicut in exacerbatione secundum diem temptationis in deserto ubi tentauerunt me patres uestri probauerunt et uiderunt opera mea

Uersus Quadraginta annis proximus fui generationi huic et dixi semper [f.24r] hii errant corde. Ipsi uero non cognouerunt uias meas quibus iuraui in ira mea si introibunt in requiem meam 
Uersus Gloria patri et filio et spiritui sancto. Sicut erat in principio et [f.24v] nunc et semper et in secular seculorum. Amen.

\section{Octauus}

Uenite exultemus domino iubilemus deo salutari nostro preoc $<\mathrm{c}>$ upemus faciem eius in confessione et in psalmis iubilemus ei.

Uersus Quoniam [f.25r] deus magnus dominus et rex magnus super omnes deos. Quoniam non repellet dominus plebem suam quia in manu eius sunt omnes fines terre et altitudines moncium ipse conspicit.

Uersus Quoniam ipsius [f.25v] est mare et ipse fecit illud et aridam fundauerunt manus eius. Uenite adoremus et procidamus ante deum ploremus coram domino qui fecit nos quia ipse est dominus deus noster nos autem populus eius et [f.26r] oues pascue eius.

Uersus Hodie si uocem eius audieritis nolite obdurare corda uestra. Sicut in exacerbatione secundum diem temptationis in deserto ubi tentauerunt me patres uestri probauerunt et [f.26v] uiderunt opera mea

Uersus Quadraginta annis proximus fui generationi huic et dixi semper hii errant corde. Ipsi uero non cognouerunt uias meas quibus iuraui in ira mea si introibunt in requiem meam [f.27r]

Uersus Gloria patri et filio et spiritui sancto. Sicut erat in principio et nunc et semper et in secular seculorum. Amen.

Incipit officium in agenda mortuorum ${ }^{51}$

ad uesperas

antiphona $\mathrm{P}_{\text {lacebo domino in regionem uiuorum }}{ }^{52}$

psalmus $\mathrm{D}_{\text {ilexi quoniam }}{ }^{53}$

antiphona [f.27v] Heu michi quia incolatus meus prolongatus est $\mathrm{t}^{54}$

\footnotetext{
${ }^{51}$ Cantus Feast Code: 13001000 (Pro defunctis)

${ }^{52}$ Cantus ID: 004293

${ }^{53}$ Cantus ID: 920114

${ }^{54}$ Cantus ID: 003038
} 
psalmus Ad dominum ${ }^{55}$

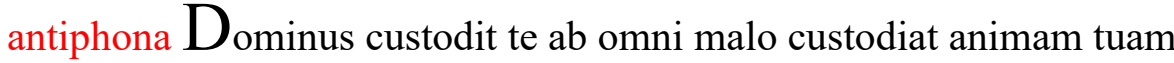
dominus $^{56}$

psalmus Leuaui $^{57}$

antiphona $\mathrm{S}_{\mathrm{i} \text { iniquitates obseruaueris domine [f.28r] domine quis sustinebit }}{ }^{58}$

psalmus De profu $<$ ndis $>^{59}$

$<$ antiphona $>\mathrm{O}_{\text {pera manuum tuarum domine ne despicias }}{ }^{60}$

psalmus Confite $<$ bor $>^{61}$

[in margine] Uersus Audiui uocem $\mathrm{d}<$ omini $>\mathrm{d}<\mathrm{icentem}>\mathrm{m}<\mathrm{ichi}>62$

Antiphonus ad magnificat

$\mathrm{O}_{\text {mne }}$ quo $<\mathrm{d}>$ dat michi pater ad me ueniet et eum qui uenit ad me non eiciam foras ${ }^{63}$ psalmus [f.28v] Mag $<$ nificat $>{ }^{64}$

Invitatorium

Regem cui omnia uiuunt ${ }^{65}$

psalmus Uenite adoremus ${ }^{66}$

Uenite exultemus domino

psalmus iubilemus deo salutari nostro preocupemus faciem eius in confessione et in psalmis iubilemus ei ${ }^{67}$

\footnotetext{
55 Cantus ID: 920076?

${ }^{56}$ Cantus ID: 002402 http://cantusindex.org/id/004293

${ }^{57}$ Cantus ID: 920120

${ }^{58}$ Cantus ID: 004899

${ }^{59}$ Cantus ID: 920129

${ }^{60}$ Cantus ID: 004159

${ }^{61}$ Cantus ID: 920110?

${ }^{62}$ Cantus ID: 001528?

${ }^{63}$ Cantus ID: 004115

${ }^{64}$ Cantus ID: 003668

65 Cantus ID: 001131

${ }^{66}$ Undetermined. Matches psalm 94:6.

${ }^{67}$ Cantus ID: 909030
} 
Uersus ...

\section{[folio cut out]}

[29r] $\ldots<$ re $>$ quiem eternam dona eis domine. Et lux perpetua luceat eis. ${ }^{68}$

Alius invitatorium

Circumdederunt me gemitus mortis

psalmus Dolores inferni circumdederunt $\mathrm{me}^{69}$

psalmus Uenite ${ }^{70}$

in primo nocturno : antiphona

Dirige domine deus me[f.29v]us inconspectu tuo uiam meam ${ }^{71}$

psalmus verba ${ }^{72}$

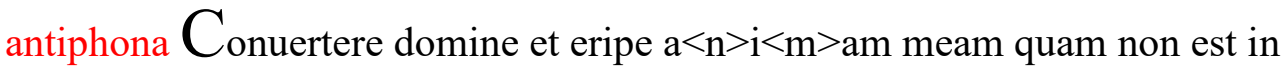
morte qui memor sit tui ${ }^{73}$

psalmus Domine ${ }^{74}$

antiphona $\mathrm{N}$ equando rapiat ut leo animam meam dum non est qui redimat [f.30r] neque qui saluum faciat ${ }^{75}$

psalmus Domine deus ${ }^{76}$

uersus A porta inferi ${ }^{77}$

responsorium Credo quod redemptor meus uiuit et in nouissimo die de terra surreturus sum

psalmus Et in carne me

\footnotetext{
${ }^{68}$ Cantus ID: 004617

${ }^{69}$ Cantus ID: 100089

${ }^{70}$ Undetermined.

${ }^{71}$ Cantus ID: 002244

72 Undetermined.

${ }^{73}$ Cantus ID: 001921

${ }^{74}$ Undetermined.

${ }^{75}$ Cantus ID: 003875

${ }^{76}$ Undetermined.

${ }^{77}$ Cantus ID: 004899za
} 
uersus a uidebo deum saluatore[f.30v]m meum ${ }^{78}$

uersus $Q$ uem uisurus sum ego ipse et non alius et occuli mei conspecturi sunt $^{79} \mathrm{Et}$ in

uersus Kyrie leyson ${ }^{80}$

responsorium Qui Lazarum resuscitasti a monumento fetidum

psalmus Tu eis domine [f.31r] dona requiem et locum indulgentie ${ }^{81}$

uersus $Q_{\text {ui uenturus es iudicare uiuos et mortuos et seculum per ignem }}{ }^{82}$

psalmus Tue ${ }^{83}$

uersus Kyrie leyson ${ }^{84}$

responsorium Domi- ne quando ueneris iudica[f.31v]re terram ubi me abscodam a uultu ire tue

psalmus Quia peccaui nimis in uita mea ${ }^{85}$

psalmus Comissa mea pauesco et ante te rubesco dum ueneris iudicare noli psalmus Quia $^{87}$ me condempna[f.32r] $\mathrm{re}^{86}$

uersus $\mathrm{R}$ equiem eternam dona eis domine et lux perpetua luceat eis ${ }^{88}$ psalmus Quia ${ }^{89}$ Kyrie leyson ${ }^{90}$

in duo nocturno : antiphona

In loco pascue ibi me collocauit ${ }^{91}$ psalmus dominus re $^{92}$

\footnotetext{
${ }^{78}$ Cantus ID: 006348

${ }^{79}$ Cantus ID: 006348a

${ }^{80}$ Cantus ID: 909040

${ }^{81}$ Cantus ID: 007477

${ }^{82}$ Cantus ID: 007477b

${ }^{83}$ Undetermined.

${ }^{84}$ Cantus ID: 909040

${ }^{85}$ Cantus ID: 006507

${ }^{86}$ Cantus ID: 006107a

${ }^{87}$ Undetermined.

${ }^{88}$ Cantus ID: 007091u

${ }^{89}$ Undetermined.

${ }^{90}$ Cantus ID: 909040

${ }^{91}$ Cantus ID: 003250

${ }_{92}$ Undetermined.
} 
$<$ antiphona $>$ Delicta iuuentutis mee et igno[f.32v]rantias meas ne memineris domine $^{93}$

psalmus Ad te domine

antiphona $C_{\text {redo uidere bona domini }}{ }^{94}$ in terra uiuencium ${ }^{95}$

psalmus Dominus illu ${ }^{96}$

uersus Collocet eos dominus ${ }^{97}$

responsorium Memento mei deus quia uentus est uita mea

psalmus Nec aspici [f.33r] et me uisus hominis ${ }^{98}$

uersus De profundis clamaui ad te domine domine exaudi uocem meam psalmus $\mathrm{Nec}^{99}$

responsorium Heu michi domine quia peccaui nimis in uita mea quid faciam miser $\mathrm{u}[\mathrm{f} .33 \mathrm{v}] \mathrm{bi}$ fugiam nisi ad te deus meus miserere mei

psalmus Dum ueneris in nouissimo die ${ }^{100}$

uersus Anima mea turbata est ualde sed tu domine sucurre ei ${ }^{101}$

psalmus Mise $<\ldots>^{102}$

[missing folio]

[f.34r] Kyrie leyson ${ }^{103}$

responsorium Ne recorderis peccata mea domine

psalmus Dum ueneris iudicare seculum per ignem ${ }^{104}$

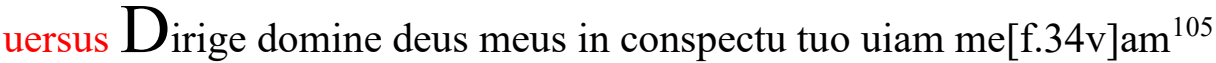
uersus Dum ${ }^{106}$

psalmus Requiem eternam dona eis domine et lux perpetua luceat eis ${ }^{107}$ psalmus Dum ${ }^{108}$

antiphona in tertio nocturno

\footnotetext{
${ }^{93}$ Cantus ID: 002146

${ }^{94}$ Cantus ID: 008000

${ }^{95}$ See also Cantus ID: 001948

${ }^{96}$ Undetermined.

${ }^{97}$ Cantus ID: 800066

${ }^{98}$ Cantus ID: 007143

${ }^{99}$ Cantus ID: g02286

${ }^{100}$ Cantus ID: a00411

${ }^{101}$ Cantus D: 006811a

102 Undetermined.

${ }^{103}$ Cantus ID: 909040

${ }^{104}$ Cantus ID: 007209

${ }^{105}$ Cantus ID: 002244

${ }^{106}$ Cantus ID: 007091zaz

${ }^{107}$ Cantus ID: 004617

${ }^{108}$ Cantus ID: 007091zaz
} 
Complaceat tibi domine ut eripias me ad adiuuandum me respice ${ }^{109}$ psalmus Expectans ${ }^{110}$

antiphona $S_{\text {ana }}$ [f.35r] domine animam meam quia peccaui tibi ${ }^{111}$ psalmus Beatus qui ${ }^{112}$

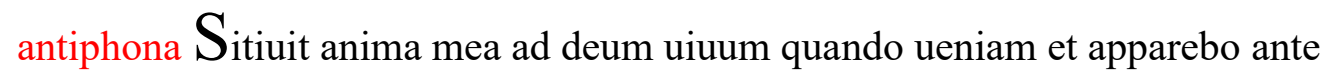
faciem domini ${ }^{113}$

psalmus Quemad $<$ modum $>^{114}$

uersus $\mathrm{Ne}$ tradas bestiis ${ }^{115}$

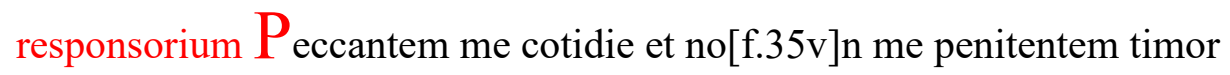
mortis conturbat me

psalmus Quia in inferno nulla est redemptio miserere mei deus et salua me $e^{116}$

uersus Deus in nomine tuo saluum me fac et in uirtute tua libera me $\mathrm{e}^{117}$

psalmus Quia : kyrie leyson ${ }^{118}$

responsorium [f.36r] Domine secundum actum meum noli me iudicare nichil dignum in conspectu tuo egi ideo deprecor maiestatem tuam

psalmus Ut tu deus deleas iniquitatem me[f.36v]am ${ }^{119}$

uersus $\mathrm{Amplius}$ laua me domine ab iniusticia mea et a delicto meo munda $\mathrm{me}^{120}$

psalmus Ut kyrie leyson ${ }^{121}$

responsorium Libera me domine de $u i<\mathrm{i}>\mathrm{s}$ inferni qui portas ereas confregisi et uisitasti infer[f.37r]num et dedisti eis lumen ut uiderent te

psalmus Qui erant in $\mathrm{p}<\mathrm{0}>$ enis tenebrarum ${ }^{122}$

uersus $C_{\text {lamantes et dicentes aduenisti redemptor noster }}{ }^{123}$

psalmus Qui e $<$ rant $>\quad$ kryie leyson ${ }^{124}$

responsorium Libera me domine de morte eterna in die illa $[\mathrm{f} .37 \mathrm{v}]$ tremenda

[later addition : Christe leyson, kyrie leyson]

\footnotetext{
${ }^{109}$ Cantus ID: 001861

${ }^{110}$ Cantus ID: 007698a?

${ }^{111}$ Cantus ID: 004696

${ }^{112}$ Cantus ID: g01123a?

${ }^{113}$ Cantus ID: 004972

${ }^{114}$ Cantus ID: 920041?

${ }^{115}$ Cantus ID: 800289

${ }^{116}$ Cantus ID: 007368

${ }^{117}$ Cantus ID: 007368a

${ }^{118}$ Cantus ID: 909040

${ }^{119}$ Cantus ID: 006512

${ }^{120}$ Cantus ID: 007209za

${ }^{121}$ Cantus ID: 909040

${ }^{122}$ Cantus ID: 007092

${ }^{123}$ Cantus ID: 007092a

${ }^{124}$ Cantus ID: 909040
} 
psalmus Quando celi mouendi sunt et terra

psalmus Dum ueneris iudicare seculum per ignem ${ }^{125}$

uersus $T$ remens factus sum ego et timeo dum discusio uenerit atque uentura ira $^{126}$

psalmus Quando ${ }^{127}$

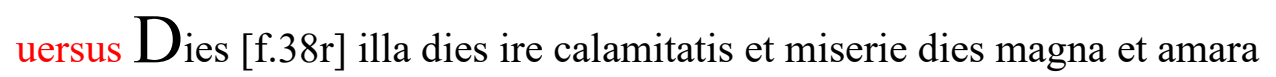
ualde

psalmus Dum ${ }^{128}$

uersus $\mathrm{R}$ equiem eternam dona eis domine et lux perpetua luceat eis ${ }^{129}$ responsorium Libera ${ }^{130} \quad$ kyrie leyson. christe leyson. kyrie leyson. ${ }^{131}$

Ad laudes antiphonus [f.38v]

Exultabunt domino ossa humiliata ${ }^{132}$

psalmus Miserere ${ }^{133}$

antiphona Exaudi domine orationem meam ad te omnis caro ueniet ${ }^{134}$ psalmus Te de ${ }^{135}$

antiphona $\mathrm{Me}$ suscepit dextera tua domine ${ }^{136}$

psalmus Deus deus

antiphona $A$ porta inferi erue domine ${ }^{137}$ [f.39r] animam meam ${ }^{138}$

psalmus Ego di $<$ xi $>$

antiphona $\mathbf{O}_{\text {mnis spiritus laudet dominum }}{ }^{139}$

psalmus Laudate

uersus Audiui uocem ${ }^{140}$

Ad benedictio

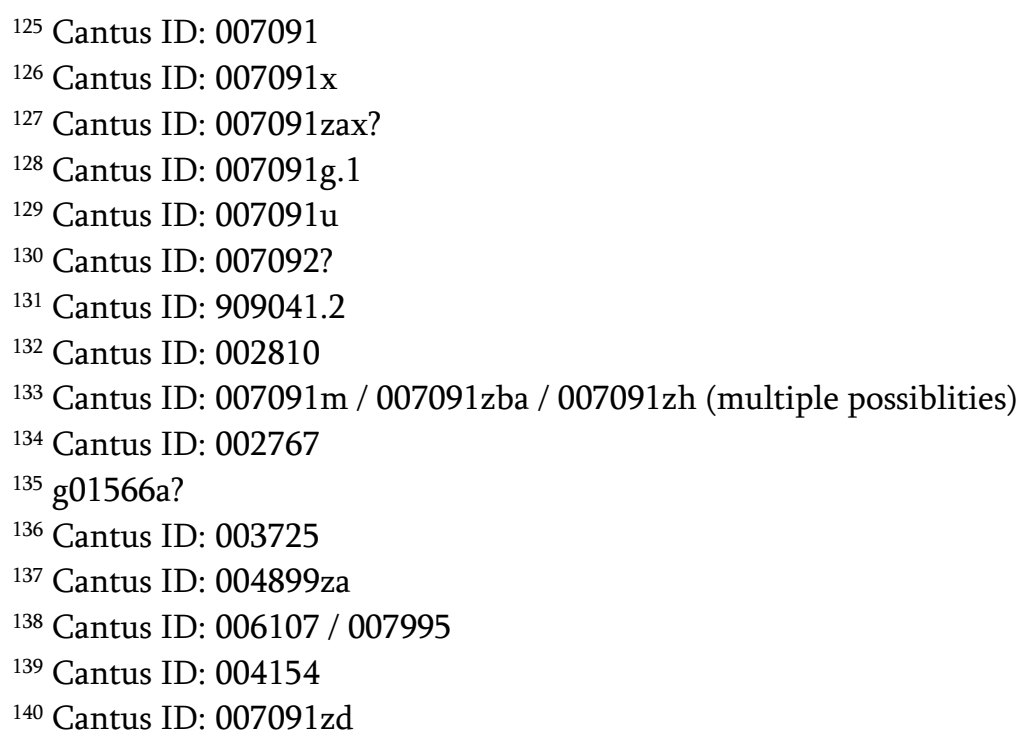


Ego sum resurrectio et uita qui credit in me etiam si mortuus fuerit uiuet et om $<\mathrm{n}>$ is qui credit in me non morietur in eternum ${ }^{141}[\mathrm{f} .39 \mathrm{v}]$ psalmus Benedi $<$ ctus $>^{142}$

responsorium Subuenite sancti dei occurrite angeli domini psalmus Suscipientes animam euis psalmus Offerentes eam in conspectu altissimi ${ }^{143}$

uersus Suscipiat te Christus qui creauit te et in [f.40r] sinu Abrae angeli deducant te $\mathrm{e}^{144}$

psalmus Susci $<$ pientes $>145$

uersus $\mathrm{R}$ equie in eternam dona eis domine et lux perpetua luceat $\mathrm{ei}^{146}$ psalmus Offerentes kyrie leyson ${ }^{147}$

responsorium In paradisum deducant te angeli in tuo ad uentu suscipiat te [f.40v] martires et perducant te in ciuitatem sanctam iherusalem uersus Chorus angelorum te suscipiat et cum lazaro quondam paupere eternam habeau requiem ${ }^{148}$

antiphonus in personae defu $<\mathrm{n}>$ cti dicat

Aperite michi portas iusticie et ingressus in eas confitebor domino ${ }^{149}$ psalmus [f.41r] Confitemini. deus ${ }^{150}$

antiphona Ingrediar in locum tabernaculi admirabilis usquam ad domum dei ${ }^{151}$ psalmus Quemad $<$ modum $>152$

antiphona Nec requies mea in seculum seculi hic habitabo quoniam elegi eam $^{153}$

psalmus $\mathrm{O}$ demento

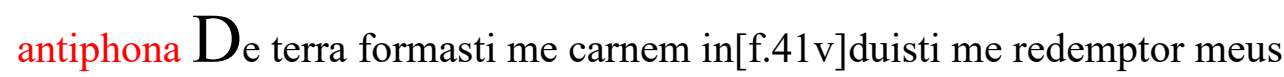
domine resuscita me in nouissimo die $^{154}$

psalmus Domine probas $<\mathrm{ti}>155$

\footnotetext{
${ }^{141}$ Cantus ID: 002601

142 Undetermined.

${ }^{143}$ Cantus ID: 007716

${ }^{144}$ Cantus ID: 007716a

145 Undetermined.

${ }^{146}$ Cantus ID: 007477a

${ }^{147}$ Cantus ID: 909040

${ }^{148}$ Cantus ID: g01587

${ }^{149}$ Cantus ID: a00221

${ }^{150}$ Undetermined.

${ }^{151}$ Cantus ID: 003335

152 Undetermined.

${ }^{153}$ Cantus ID: 003012

${ }^{154}$ Cantus ID: 002123

155 Cantus ID: 920138?
} 


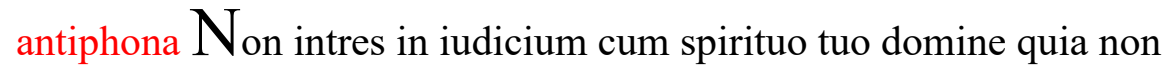
iustificabitur in conspectu tuo omnis uiuens ${ }^{156}$

psalmus Domine exa< audi> .i. ${ }^{157}$

antiphona [f.42r] $\mathrm{O}_{\text {mnis spiritus laudet dominum }}{ }^{158}$

psalmus Laudate domine deus ${ }^{159}$

antiphona Ego sum ${ }^{160}$

[new hand]

patrem omnipotentem $\mathrm{fa}<\mathrm{c}>$ torem celi et terra visi $<\mathrm{b}>$ ilium omnium et invisi $<b>$ ilium et in unum dominum ihesum christum filium dei unige $<$ ni $>$ tum Et ex patre [f.42v] natum ante om $<$ n $>$ ia secula, deum de deo, lumen de lumine, deum verum de deo vero, genitum non factum, consustancialem ${ }^{161}$ patri per quem omnia facta sunt qui propter nos homines et propter nostram salutem desce $<\mathrm{n}>$ dit de celis fa $<\mathrm{c}>$ tus est crucifixus eciam pro nobis sub pontio pilato, [f.43r] passus et sepultus est, et resurrexit tercia die. Secundum scrituras et ascendit in celum sedet ad dexteram patris et iterum venturus est cum gloria iudicare uiuos et mortuos cuius Regni non erit finit et in spiritum sanctum domininum et uiuificantem qui ex patre filioque proçedit ${ }^{162}[43 \mathrm{v}]$

Blank folio. [44r]

Sabbato in aduentum domini. Hymnus ${ }^{163}$

Conditor alme siderum, eterna lux creden $<p>$ tium Qui $<\ldots>^{164}$ christe redemptor omnium exaudi preces supplicum

ad nona

Uerbum supernum prodiens a patre olim exiens qui natus orbi subuenis cursu decliui temporis. Illumina $<\ldots>^{165}[\mathrm{f} .44 \mathrm{v}]$

Ad laudes

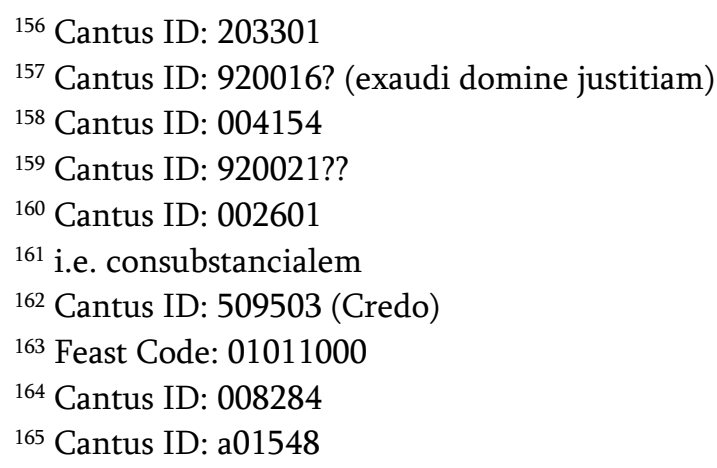


Uox clara ecce intonat ${ }^{166}$

Hymnus in natalis domini ad uesperas et ad nona ${ }^{167}$

Christe redemptor omnium ex patre patris unice solus ante principium natus ineffabiliter Tu lumen ${ }^{168}$

ad laudes

A solis or $<\mathrm{t}>$ us cardine ad usque terre limitem christum canamus principem [f.45r]

natum maria uirgine Beatus ${ }^{169}$

in epiphania domini ${ }^{170}$

Hostis herodes impie christum uenire quid times non arripit mortalia qui regna dat celestia ${ }^{171}$ Ibant $^{172}$

sabbato quadragesime hymnus ${ }^{173}$

Audi benigne conditor nostras preces cum fletibus in hoc sacro ieiunio $[\mathrm{f} .45 \mathrm{v}]$

fusas quadragenario Scrutator ${ }^{174}$

ad nona

Ex more docti mistico seruemus hoc ieiunium deno dierum circulo ducto quater notissimo Lex $^{175}$

ad laudes

166 Cantus ID: 008413

167 Feast Code: 02122500

${ }^{168}$ Cantus ID: ah02022

${ }^{169}$ Cantus ID: 008248.1

170 Feast Code: 05010600

${ }^{171}$ Cantus ID: 830364

${ }^{172}$ Cantus ID: 008248h

${ }^{173}$ Feast code: 07007000

${ }^{174}$ Cantus ID: 008267.1

175 Cantus ID: 008300.2 
Iam criste sol iusticie mentis dehiscant tenebre uirtutum ut lux redeat terris diem cum re[f.46r]para Dans ${ }^{176}$

in dominicis diebus

Aures ad nostras deitatis preces deus inclina pietate sola supplicum uota suscipe precamur famuli tui ${ }^{177}$ Respice ${ }^{178}$

in dominica de passione ${ }^{179}$

Uexilla regis prodeunt fulget crucis misterium quo carne carnis conditor suspensus [f.46v] est patibulo Quo ${ }^{180}$

ad nona

$\mathrm{P}_{\text {ange }} \mathrm{li}<\mathrm{n}>$ gua gloriosi prelium certaminis et super crucis tropheum dic triumphum nobilem qualiter redemptor orbis immolatus uicerit $\mathrm{De}^{181}$

ad laudes

Lustris sex qui ${ }^{182}$

dominica prima post pascha ${ }^{183}$

Ad cenam agni prouidi et stolis albis [f.47r] candidi post transitum maris rubri christo canamus principi Cuius ${ }^{184}$

ad nona

Rex externe ${ }^{185}$

ad laudes

\footnotetext{
${ }^{176}$ Cantus ID: 008325

177 Cantus ID: 008269 (Dom. 1 Quadragesimae)

${ }^{178}$ Cantus ID: 008269a

179 Feast Code: 07051000

${ }^{180}$ Cantus ID: 008410.1

${ }^{181}$ Cantus ID: g00960.1

${ }^{182}$ Cantus ID: g00965.1

183 Feast Code: 08021000

${ }^{184}$ Cantus ID: 008249

${ }^{185}$ Undetermined.
} 
Aurora ${ }^{186}$

in uigilia ascensio ${ }^{187}$

Ihesu nostra redemptio amor et desiderium deus creator omnium homo in fine temporum Que te ${ }^{188}$

ad nona

Eterne rex [f.47v] altissime redemptor et fidelium quo mors soluta deperit datur triumphus gratie ${ }^{189}$ Scandens ${ }^{190}$

In uigilia sancto pentacosta ${ }^{191}$

Ueni creator spiritus mentes tuorum uisita imple superna gratia que tu creasti pectora Qui ${ }^{192}$

ad nona

Iam christus astra ascenderat regressus [f.48r] unde uenerat promissum patris munere sanctum daturus spiritum Solennis ${ }^{193}$

ad laudes

Beata nobis ${ }^{194}$

in festo trinitatis ${ }^{195}$

In maiestatis solio tres sedent in triclinio nam non est consolatio perfecto solitario Eterne ${ }^{196}$

ad nona

lux beata trinitas ${ }^{197}[\mathrm{f} .48 \mathrm{v}]$ tres $\mathrm{un}<\mathrm{u}>\mathrm{m}$ trium unio imperialis unitas in trium contubernio $\mathrm{O}$ pater in nas $<$ cibilis $>198$

${ }^{186}$ Cantus ID: 008271

${ }^{187}$ Feast Code: 08065000

${ }^{188}$ Cantus ID: g01595

${ }^{189}$ Cantus ID: 008255.1

${ }^{190}$ Cantus ID: 008255b

${ }^{191}$ Feast Code: 08081000

${ }^{192}$ Cantus ID: g01590.1

${ }^{193}$ Cantus ID: 008327.1

${ }^{194}$ Cantus ID: 008273

195 Feast Code: 09011000

196 Cantus ID: 830370

${ }^{197}$ Cantus ID: 008358

${ }^{198}$ Undetermined. 
ad laudes

Festi laudes hodierni ritu ductas annuo ciues gaudio superni celebrant perpetuo regem trinum dum tertrini chori laudent mutuo Uita melos ${ }^{199}$

de corpore christi hymnus ${ }^{200}[\mathrm{f} .49 \mathrm{r}]$

$\mathrm{P}_{\text {ange lingua gloriosi corporis misterium sanguinisque preciosi quem in }}$ mundi precium fructus uentris generosi rex effudit gentium Nobis ${ }^{201}$

ad nona

Sacris solenniis iuncta sint gaudia et ex precordiis sonent preconia recedant uete[f.49v]ra noua sint omnia corda uoces et opera Noctis ${ }^{202}$

ad laudes

Uerbum supernum prodiens nec patris linquens dexteram ad opus suum exiens uenit ad uite uesperam $\operatorname{In}^{203}$

sabbato ad uesperas

O lux beata trinitas et principalis unitas iam [f.50r] sol recedit igneus infunde lumen cordibus $\mathrm{Te}^{204}$

dominico ad uesperas

Lucis creator optime lucem dierum proferens primordiis lucis noue mundi parans originem Qui ${ }^{205}$

in conuersione sancti pauli ${ }^{206}$ hymnus

Doctor egregie Paule mores instrue et mente polum [f.50v] nos transferre satage donec perfectum largiatur plenius euacuato quod ex parte gerimus Sit trinitati sempiterna gloria honor potestas atque iubilatio in unitate cui manet inperum ex tunc et modo per eterna secula Amen ${ }^{207}$ [f.51r]

\footnotetext{
199 Undetermined.

${ }^{200}$ Feast Code: 09015000

${ }^{201}$ Cantus ID: 830393

${ }^{202}$ Cantus ID: 830301

${ }^{203}$ Cantus ID: g01593.1

${ }^{204}$ Cantus ID: 008358

${ }^{205}$ Cantus ID: 008337

${ }^{206}$ Feast Code: 14012500

${ }^{207}$ Cantus ID: a01567
} 
in cathedra sancti petri ${ }^{208}$ ad uesperas et nona

Quodcumque uinclis super terram strinxerit erit in astris religatum fortiter et quod resoluit in terris arbitrio erit solutum super celi radium infine mundi iudex erit seculi ${ }^{209}$ Gloria deo per immensa secula sit tibi nate decus et imperium ho[f.51v]nor potestas sanctoque spiritui sit trinitati salus indiuidua per infinita seculorum secula Amen ${ }^{210}$

ad laudes

Iam bone pastor Petre clemens accipe uota precantum et peccati uincula resolue tibi potestate tradita qua cunctis celum uerbo [f.51v] claudis aperis ${ }^{211}$ Sit trinitati ${ }^{212}$

in sancti antonii ${ }^{213}$ ad uesperas hymnus

En gratulemur hodie christo regi iocundius in cuius aula glorie iam iubilat antonius Francisci ${ }^{214}$

ad nona

Laus regi plena gaudio que merces militantium seipsum dat antonio militie stipendium $\operatorname{In}^{215}[\mathrm{f} .52 \mathrm{v}]$

ad laudes

Iesu lux uera mencium ${ }^{216}$

ad uesperas

$\mathrm{C}<\mathrm{h}>$ ori nostri preconium laudes resultet domino miranda per antonium more patranti pristino Tiberi ${ }^{217}$

in sancti ioanne baptiste ${ }^{218}$

208 Feast Code: 14022200

${ }^{209}$ Cantus ID: 008302d

${ }^{210}$ Cantus ID: a01133.1 *not an exact match

${ }^{211}$ Cantus ID: 008268b

${ }^{212}$ Cantus ID: 008268h

${ }^{213}$ Feast Code: 14061300

${ }^{214}$ Cantus ID: a01924

${ }^{215}$ Cantus ID: 830354.1

${ }^{216}$ Cantus ID: 830353

${ }^{217}$ Undetermined.

${ }^{218}$ Feast Code: 14062400 
$\mathrm{U}_{\mathrm{t}}$ queant laxis resonare fibris mira gestorum famuli tuorum solue polluti labii reatum [f.53r] sante ioannes Nuncius ${ }^{219}$

ad nona

Antra deserti 220

ad laudes

$\mathrm{O}$ nimis $\mathrm{fe}<\mathrm{lix}>221$

in sanctorum petri et pauli ${ }^{222}$

Aurea luce et decore roseo lux lucis omne perfudisti seculum decorans celos inclito martirio hac sacra die que dat reis ueniam Ianito $<\mathrm{r}>$ celi doctor [f.53v] orbis pariter iudices seculi uera mundi lumina per crucem alter alter ense triumphans uite senatum laureati possidet $\mathrm{Sit}^{223}$

in sancte mariae magdalene

Nardi maria pistici sumpsit libram mox optimi unxit beatos domini pedes rigando [f.54r] lachrimis Honor decus imperium sit trinitati unice patri nato paraclito per infinita secula Amen ${ }^{224}$

in uincula sancti petri ${ }^{225}$

Petrus beatus cathenarum laqueos christo iubente rupit mirabiliter custos ouilis et doctor ecclesie pastorque gregis conseruator $[\mathrm{f} .54 \mathrm{v}] \mathrm{o}<\mathrm{m}>$ nium arcens luporum truculentam rabiem ${ }^{226}$ Gloria

in $\operatorname{tra}<$ n $>$ sfiguratio domini ${ }^{227}$ ad uesperas

$<\mathrm{G}>$ aude $^{228}$ mater pietati in ua $<1>$ le gementium pro ducatu dignitatis christi regis omnium quo dilecta predotaris in culmine montium ${ }^{229} \mathrm{Ubi}^{230}$

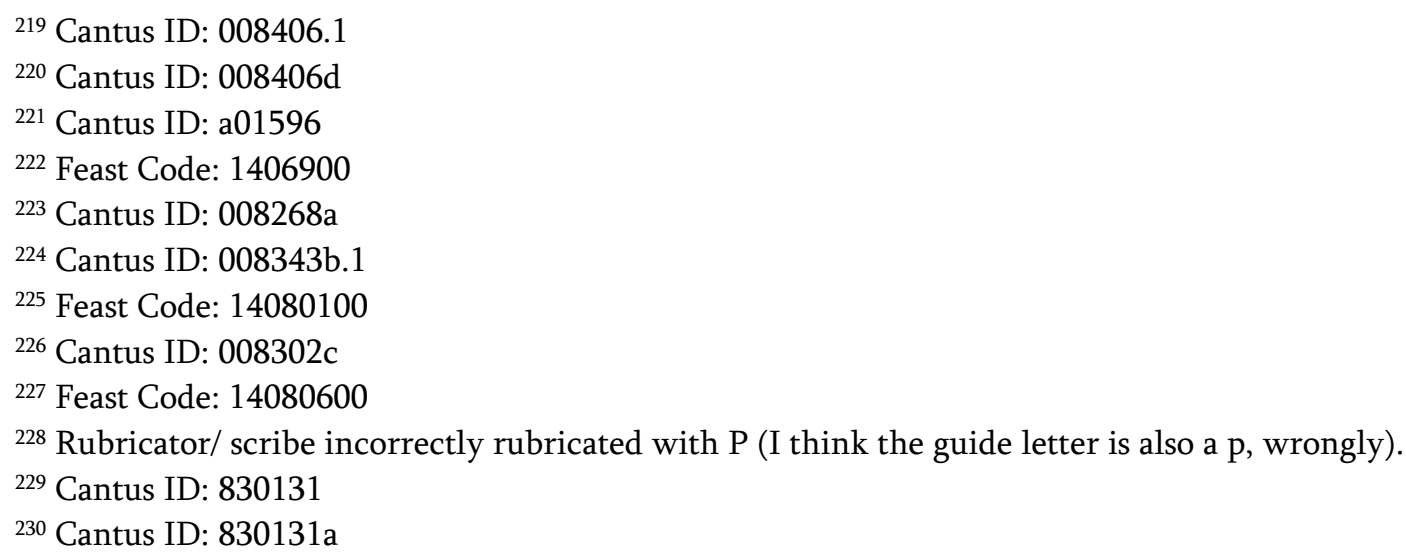


ad nona

Exultet laudibus [f.55r] sacrata concio celi agminibus iuncta tripudio pro uerbi gratia qua splendent omnia terra pontus et ethera ${ }^{231}$ Promis $^{232}$ ad laudes

Nouum sidus exoritur christi pia clementia quo tenebrosa premitur inimici seuitia Insurgere ${ }^{233}$

in sancte clare ${ }^{234}$ ad uesperas hymnus [f.55v]

Concinat plebs fidelium vir ${ }^{235}$

ad nona

Generat virgo filias ${ }^{236}$

ad laudes

clara luce clarior ${ }^{237}$

ad uesperas

En preclara uirgo clara ${ }^{238}$

in assumptione beate marie $\mathrm{e}^{239}$

Aue maris stella dei mater alma adque semper uirgo felix celi porta Sumens ${ }^{240}$

ad nona

${ }^{231}$ Cantus ID: 830439

${ }^{232}$ Cantus ID: 830439a

233 Undetermined.

${ }^{234}$ Feast Code: 14081200

${ }^{235}$ Cantus ID: 830348

${ }^{236}$ Cantus ID: 830350

${ }^{237}$ Cantus ID: a02008

238 Undetermined.

${ }^{239}$ Feast Code: 14081500

${ }^{240}$ Cantus ID: 008272.1 
Quem [f.56r] terra pontus ethera colunt adorant predicant trinam regentem machinam claustrum marie baiulat ${ }^{241}$

ad laudes

gloriosa domina ${ }^{242}$

in sancti ludouici confessoris ${ }^{243}$

Uergente mundi uespere sol ${ }^{244}$

ad nona

Dum medium silentium ${ }^{245}$

ad laudes

$\mathrm{U}_{\mathrm{t}}$ lux aurore rutilat ${ }^{246}$

ad uesperas

Ludouicus ut ami ${ }^{247}[\mathrm{f} .56 \mathrm{v}]$

in sancti michaelis ${ }^{248}$ : hymnus

Tibi christe splendor patris uita uirtus cordium in conspectu angelorum uotis uoce psallimus alternantes concrepando melos damus uocibus ${ }^{249}$

ad laudes

Christe sanctorum decus angelorum rector humani generis et auctor nobis [f.57r] eternum tribue benignus scandere celum ${ }^{250}$

\footnotetext{
${ }^{241}$ Cantus ID: 008375

${ }^{242}$ Cantus ID: 007270

${ }^{243}$ Feast Code: 14082500

${ }^{244}$ Undetermined.

245 Undetermined.

${ }^{246}$ Undetermined.

247 Undetermined.

${ }^{248}$ Feast Code: 14092900

${ }^{249}$ Cantus ID: 008403

${ }^{250}$ Cantus ID: 008279
} 
In sancti francisci

Proles de celo prodiit ${ }^{251}$

ad nona

In $<$ c $>$ elesti $^{252}$ collegio ${ }^{253}$

ad laudes

Plaude turba ${ }^{254}$

ad uesperas

Decus morum dux minorum franciscus tenens brauium interite datur uite christe redemptor omnium ${ }^{255}[\mathrm{f} .57 \mathrm{v}]$

in festo omnium sanctorum

Christe redemptor omnium conseruatuos famulos beate semper uirginis placatus sanctis precibus ${ }^{256}$ Beata $^{257}$

ad laudes

Iesu saluator ${ }^{258}$

in natali apostolorum ${ }^{259}$

Exultet celum laudibus resultet terra gaudiis apostolorum gloria sacra canunt solennia ${ }^{260}[\mathrm{f} .58 \mathrm{r}]$

ad nona

\footnotetext{
${ }^{251}$ Cantus ID: 830360

${ }^{252}$ Scribe wrote a "e" for c, "eelesti"

${ }^{253}$ Cantus ID: 830351

${ }^{254}$ Cantus ID: 830359

${ }^{255}$ Cantus ID: 830096

${ }^{256}$ Cantus ID: 008276

${ }^{257}$ Cantus ID: 008276a

${ }^{258}$ Cantus ID: 008333

${ }^{259}$ Feast Code: 12019000

${ }^{260}$ Cantus ID: 008301
} 
Eterna christi munera apostolorum gloria laudes canentes debitas letis canamus mentibus Ecclesiarum ${ }^{261}$

de uno martire 262

Deus tuorum militum sors et corona premium laudes canentes martiris absolue nexu criminis $\mathrm{Hic}^{263}$

ad laudes hymnus [f.58v]

Martir dei qui unicum patris sequendo filium uictis triumphans hostibus uictor fruens celestibus Tui ${ }^{264}$

de plurimorum martirum ${ }^{265}$ hymnus

Sanctorum meritis inclita gaudia pangamus socii gestaque fortia nam gliscit animus promere cantibus [f.59r] uictorum genus optimum Hi sunt ${ }^{266}$

ad nona

Eterna cristi ${ }^{267}$

ad laudes

Rex gloriose martirum corona confitentium qui respuentes terrena perducis ad celestia Aurem ${ }^{268}$

In natum confessoris pontifi $<\mathrm{ci}>269$

Iste confessor domini sacratus festa plebs cuius celebrat per orbem hodie lec[f.59v]tus meruit secreta scandere celi ${ }^{270}$

ad laudes

\footnotetext{
${ }^{261}$ Cantus ID: a01580

${ }^{262}$ Feast Code: 12002000

${ }^{263}$ Cantus ID: 008294.1

${ }^{264}$ Cantus ID: 008346

${ }^{265}$ Feast Code: 12003000

${ }^{266}$ Cantus ID: 008390

${ }^{267}$ Cantus ID: 008252?

${ }^{268}$ Cantus ID: 008386.1

${ }^{269}$ Feast Code: 12004100

${ }^{270}$ Cantus ID: 008323
} 
Iesu redemptor omnium perpes corona presulum in hac die clementius nostris faueto precibus Tui ${ }^{271}$

non pontifici ${ }^{272}$ ad laudes

Iesu corona celsior ${ }^{273}$

de uirginum ${ }^{274}$

Iesu corona uirgi ${ }^{275}$

ad nona

Uirginis proles opifexque matris [f.60r] uirgo quem gessit peperitque $<$ virgo $>$ $\mathrm{u}<\mathrm{ir}>$ ginis fes- tum canimus tropheum accipe uotam $\mathrm{Hec}^{276}$

in dedicatione $<$ ecclesie $>$

Urbs beata hierusalem dicta pacis uisio que construitur in celis uiuis ex lapidibus et angelis $\mathrm{c}<$ oro $>$ nata $^{277}$ ut sponsata comite ${ }^{278}$

ad laudes [f.60v]

Angularis ${ }^{279}$

ad primam

Iam lucis orto sidere deum precemur suplices ut in diurnis actibus nos seruet anocetibus $^{280}$

ad terciam

Nunc sancte nobis spiritus unum patri cum filio dignare promptus ingeri nostro refusus pectori ${ }^{281}$

ad sextam

\footnotetext{
${ }^{271}$ Cantus ID: a01586

272 Feast Code: 12004700

${ }^{273}$ Cantus ID: a01587

${ }^{274}$ Feast Code: 12007000

${ }^{275}$ Cantus ID: 008330

${ }^{276}$ Cantus ID: a01588

277 Scribe writes "choornata "

${ }^{278}$ Cantus ID: 008405

${ }^{279}$ Cantus ID: 008405d

${ }^{280}$ Cantus ID: 008328

${ }^{281}$ Cantus ID: 008354 (Dom. per annum)
} 
Rector potens uerax des qui [f.61r] temperas rerum uices splendore mane instruis et ignibus meridiem ${ }^{282}$

ad nonam

Rerum deus tenax uigor immotus in te permanens lucis diurne tempora successibus determinans $T$ e lucis ante terminum rerum creator poscimus ut solita clementia [f.61v] sis presul ad custodiam ${ }^{283}$

in uisitatione beate marie ${ }^{284}$

In mariam uite uiam matrem ueram uiuentium pie uenit qui redemit $\mathrm{p}<\mathrm{e}>\mathrm{cta}$ delinquentium Gressum cepit ${ }^{285}$

ad nonam $[62 \mathrm{r}]$

[rest cut off... end of first manuscript]

Lamentatio Jeremie prophete ${ }^{286}$

Incipit lamentatio ieremie prophete

Aleph

Quomodo sedet sola ciuitas plena populo facta est quasi uidua domina gencium princeps prouinciarum facta est sub tributo ${ }^{287}$

Beth

Plorans plorauit in nocte et lacri[f.62v]me eis in maxillis eius non est qui consoletur eam ex $0<\mathrm{m}>$ nibus caris eius omnes amici eius spreuerunt eam et facti sunt ei inimici ${ }^{288}$ I herusalem. iherusalem. conuertere ad dominum deum tuum $^{289}$

$\mathrm{ORO}^{290}$

\footnotetext{
${ }^{282}$ Cantus ID: 008380 (Dom. per annum)

${ }^{283}$ Cantus ID: 008382 (Dom. per annum)

${ }^{284}$ Feast Code: 14070200

${ }^{285}$ Cantus ID: 830161

${ }^{286}$ An essential text used for the services of Tenebrae (3 days preceding Easter)

${ }^{287}$ Cantus ID: 850096

${ }^{288}$ Cantus ID: 850096a

${ }^{289}$ Cantus ID: 850330

${ }^{290}$ Oratio, In Sabbato Sancto, Feast Code: 07067000. Rubrication ambiguous.
} 
Incipit oracio ieremie prophete ${ }^{291}[\mathrm{f} .63 \mathrm{r}]$

Recordare domine quid acciderit nobis intuere et respice obprobrium nostrum. ${ }^{292}$ Hereditas nostra uersa est ad alienos domus nostre ad extraneos: ${ }^{293}$ pupilli facti sumus absque patre matres nostre [f.63v] quasi uidue. ${ }^{294}$ Aquam nostram peccunia bibimus. Ligna nostra precio conparauimus. ${ }^{295}$ Ceruicibus minabamur lapssis non dabatur requies. Egipto dedimus manum et Assiriis ut [f.64r] saturaremur pane ${ }^{296}$ Patres nostri pecauerunt et non sunt et nos iniquitates eorum portauimus. ${ }^{297}$ Serui dominati sunt nostri et non fuit qui redimeret de manibus eorum ${ }^{298}$ in animabus [f.64v] nostris afferebamus panem nobis a facie gladii in deserto. ${ }^{299}$ Pellis nostra quasi clibanus exusta est a facia tenpestatum famis. ${ }^{300}$ Mulieres in sion humiliauerunt uirgines in ciuitatibus iuda $^{301}[\mathrm{f} .65 \mathrm{r}]$

$<\ldots$ page missing $>$

[65r] [Conceptio Marie Virginis: antiphona]

$<$ Decuit virginem ea pur $>$ itate nitere qua major sub deo nequit intellegi alleluya $^{302}$

psalmus $\mathrm{N}_{\text {isi dominus }}{ }^{303}$

antiphona $\mathrm{Hec}_{\mathrm{est}}$ uirga in qua nec nodus originalis nec cortex uenialis culpe fuit $^{304}$

alleluya

psalmus Lauda iherusalem ${ }^{305}$

antiphona [f.65v] Unica est columba mea una est perfecta mea una est genitricis sue electa uiderunt eam anime sancte et inmaculatam predicauerunt alleluya ${ }^{306}$

psalmus Magnifi $<$ cat $>$

\footnotetext{
${ }^{291}$ Cantus ID: 850345

${ }^{292}$ Cantus ID: 850136

${ }^{293}$ Cantus ID: 850136a

${ }^{294}$ Cantus ID: 850136b

${ }^{295}$ Cantus ID: 850136c

${ }^{296}$ Cantus ID: 850136e

${ }^{297}$ Cantus ID: $850136 \mathrm{f}$

${ }^{298}$ Cantus ID: $850136 \mathrm{~g}$

${ }^{299}$ Cantus ID: 850136h

${ }^{300}$ Cantus ID: 850136i

${ }^{301}$ Cantus ID: 850136j

${ }^{302}$ Cantus ID a01700

303 Undetermined.

${ }^{304}$ Cantus ID: a01705

305 Undetermined.

${ }^{306}$ Cantus ID: a01706
} 
$<\ldots>$

End of ms. 